\title{
Photogrammetry as a New Scientific Tool in Archaeology: Worldwide Research Trends
}

\author{
Carmen Marín-Buzón ${ }^{1}$ (D), Antonio Pérez-Romero ${ }^{1}$, José Luis López-Castro ${ }^{2}$, Imed Ben Jerbania ${ }^{3}$ \\ and Francisco Manzano-Agugliaro $4, * \mathbb{D}$
}

1 Graphic Engineering Department, University of Seville, Utrera Road, Km 1, 41013 Sevilla, Spain; carmenmarin@us.es (C.M.-B.); tao@us.es (A.P.-R.)

2 Department of Geography, History and Humanities, University of Almeria, CEIA3, 04120 Almeria, Spain; jllopez@ual.es

3 Institut National du Patrimoine, 4 Place du Château, Tunis 1008, Tunisia; ibenjerbania@yahoo.fr

4 Department of Engineering, University of Almeria, CEIA3, 04120 Almeria, Spain

* Correspondence: fmanzano@ual.es

Citation: Marín-Buzón, C.;

Pérez-Romero, A.; López-Castro, J.L.; Ben Jerbania, I.; Manzano-Agugliaro,

F. Photogrammetry as a New Scientific Tool in Archaeology: Worldwide Research Trends. Sustainability 2021, 13, 5319. https:// doi.org/10.3390/su13095319

Academic Editor: Abdelaziz Elfadaly

Received: 4 March 2021

Accepted: 4 May 2021

Published: 10 May 2021

Publisher's Note: MDPI stays neutral with regard to jurisdictional claims in published maps and institutional affiliations.

Copyright: (c) 2021 by the authors. Licensee MDPI, Basel, Switzerland. This article is an open access article distributed under the terms and conditions of the Creative Commons Attribution (CC BY) license (https:// creativecommons.org/licenses/by/ $4.0 /)$.

\begin{abstract}
Archaeology has made significant advances in the last 20 years. This can be seen by the remarkable increase in specialised literature on all archaeology-related disciplines. These advances have made it a science with links to many other sciences, both in the field of experimental sciences and in the use of techniques from other disciplines such as engineering. Within this last issue it is important to highlight the great advance that the use of photogrammetry has brought for archaeology. In this research, through a systematic study with bibliometric techniques, the main institutions and countries that are carrying them out and the main interests of the scientific community in archaeology related to photogrammetry have been identified. The main increase in this field has been observed since 2010, especially the contribution of UAVs that have reduced the cost of photogrammetric flights for reduced areas. The main lines of research in photogrammetry applied to archaeology are close-range photogrammetry, aerial photogrammetry (UAV), cultural heritage, excavation, cameras, GPS, laser scan, and virtual reconstruction including 3D printing.
\end{abstract}

Keywords: photogrammetry; archaeology; history; surveys; 3D computer graphics; remote sensing; cultural heritage; UAV; bibliometry; Scopus

\section{Introduction}

Archaeology is the study of human cultures through the analysis of their material evidence to explain the origin and development of civilizations [1]. So, archaeological sites are a valuable source of historical information [2]. The materials found at these sites are usually studied using both physical and chemical methods, from radiocarbon dating to the study of food remains in the earliest pottery [3]. Within this science, specializations such as archaeometallurgy have meant that iron has been a valuable product since the Iron Age [4]; therefore, the identification and investigation of archaeological evidence related to the production and consumption of iron is a very relevant challenge for archaeology [5]. What is clear is that it is essential to record how and where a certain material was found, and to make a scale map of the excavation for each stratum found [6]. The availability of the most accurate documentation allows in the future to take up where it left off, or even reinterpret it if another hypothesis came up later [7].

Photogrammetry is a technique which was first developed in the early 19th century [8]. The first aerial photograph was taken in 1858 by French colonel Aime Laussedat (1819-1907) [9], although Laussedat had begun his experiments to use images for topographical mapping in early 1851 [10]. Later, Austrian army captain Theodor Scheimpflug (1865-1911) carried out zonal rectification around 1900, thus laying the foundation for the differential rectification used in ortho-photography [11]. Dr Carl Pulfrich (1858-1927) built 
the first stereocomparator in 1902, which allows a 3D stereoscopic vision of the relief. Thus, the photogrammetry era began with simple terrestrial photogrammetry, based on the principles of perspective intersections, passed through stereoscopic terrestrial photogrammetry, and in its aerial version passed through balloons; an example is the 1907 photographs of Stonehenge as seen from a war balloon [12]. One of the first practical results of aerial photogrammetry (using a balloon), or mapping, was achieved by the Italian captain Cesare Tardivo (1870-1953). In 1911, he made a mosaic of Venice with balloon photographs and, in 1913, he created a 1:4000 scale mosaic of Benghazi in Libya from aerial photographs taken from an aircraft [13].

The acquisition of large-scale information has thus been a permanent feature in the history of the world and photogrammetry has played an important role in achieving this. Moreover, the digital photography associated with the development of image processing and its automation has made these techniques widely attractive for various areas of application [14]. Today, the use of online information in our environment is in great demand for all kinds of social applications and is increasingly used for research purposes. Therefore, mapping platforms such as Google Earth are widely used to provide a clear view of cultural heritage areas [15], elevation data [16], or for the improvement of national-scale land cover classification for ecosystem services improvement [17].

From conventional aircraft flights such as those mentioned above, UAV technology allows to quickly capture significant areas of land in a reasonable time and at low cost [18]. The use of UAVs has led to the widespread use of aerial photogrammetry [19] in significantly more areas than was previously available, including their potential use in archaeological surveys $[20,21]$. In fact, modern photogrammetric techniques are based on the traditional ones, but the requirements, necessary equipment and the complexity of the tasks are considerably reduced. Therefore, UAV photogrammetry can be understood as a low-cost analytical tool. It has been used in many situations where it was not possible before, such as at archaeological sites [22], or in forestry [23] and agriculture [24]. In summary, traditional surveying only allows to collect discrete data of the feature lines that determine a surface, border, slope change, etc., while the massive capture methods based on photogrammetry allow to collect continuous points of the surfaces [25].

The advance of digital photography, where the contribution of computer sciences allows the use of conventional cameras, reducing the cost of the calibrated metric cameras that were previously mandatory for photogrammetry, cannot go unmentioned. The required parameters to adjust the geometrical distortions of the image are called inherent parameters of the camera. To determine them a procedure called calibration will be performed. There are several methods and algorithms for camera calibration, some of them automatic from photographs of printed patterns, but nowadays there is free software such as the programme called Hugin 2, dedicated to the stitching of images for the construction of panoramas which, indirectly, allows both the calibration of cameras and the correction and rectification of images.

Figure 1 summarises the photogrammetric processes involved in archaeology. Firstly, the 3D object is found, and depending on the proximity to it, the photogrammetric technique is chosen: from the ground, low altitude flight (UAV), traditional flight with aeroplanes, or if it is at a high altitude from satellites (remote sensing). The second step in image acquisition is the choice of the physical sensor or vision system, which can range from a conventional camera, photogrammetric camera, LiDAR (laser imaging detection and ranging), etc. Once the 2D images or information has been obtained, the digital image processing is carried out. Here, a large number of techniques come into play, starting with image filters, since all images have a certain amount of noise; this may be due to the camera or the signal transmission medium. Generally, the noise appears as isolated pixels that take on a different grey level than their neighbours [26]. Other are arithmetic operations with images of the same scene, or combination from different points of view (stereoscopy), to later carry out automatic classification [27], shape recognition [28], or pattern prediction. To find the contours, the image is searched for areas in the image where the pixel intensity 
changes fast. usually using one of the following criteria: locations where the first derivative (gradient) of the intensity is of a magnitude greater than that of a predefined threshold, or places where the second derivative (Laplacian) of the intensity has a zero crossing. In the first case, large peaks shall be sought and in the second case, changes of sign shall be sought. All of these latter techniques can be understood as belonging to the scientific field of computer science.

Finally, metric quality results can be obtained, in many formats, to make 2D models as maps, or with all the information contained in the photograph as orthophotography, or 3D models for DEM or virtual reconstruction.
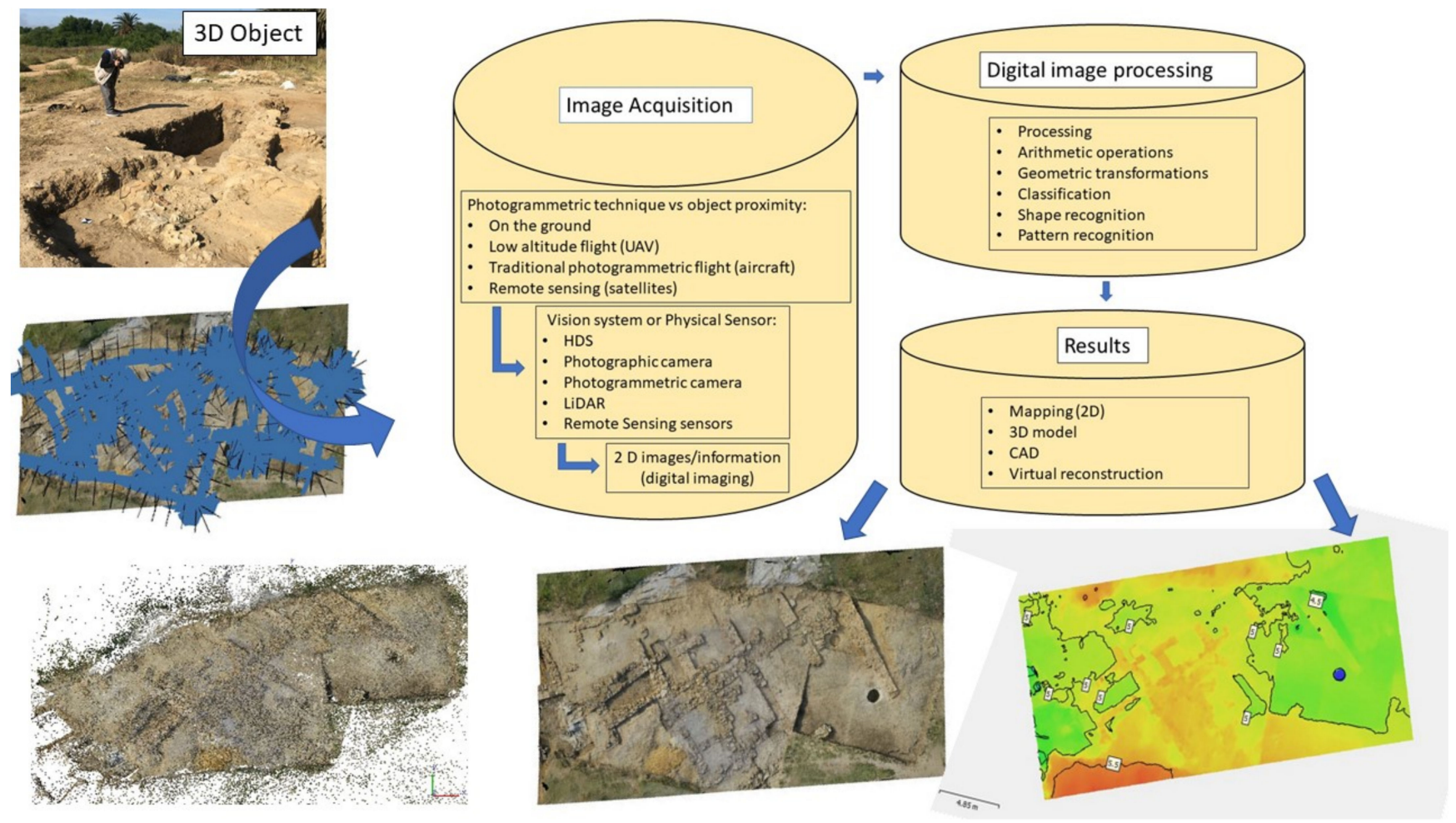

Figure 1. Summary of photogrammetric processes involved in archaeology.

It should be noted that advances in photography itself have been revolutionary milestones for photogrammetry and photointerpretation. It should be remembered that scientific advances take time to be implemented, since for example the first colour photograph by Thomas Sutton was presented by James Clerk Maxwell on 17 May 1861 at King's College, London [29]. The system was based on the discovery of the physicist Clerk Maxwell, who separated colours into magenta, cyan and yellow. Even the most recent digital cameras make use of this separation method to capture light. Colour is formed by combining the three basic colours red, green and blue (RGB). Figure 2 shows how light is separated into its three main directions, RGB, and how the result is the grey scale. A digital image can now be understood as a two-dimensional array of pixels with different luminous intensity (grey scale). Thus, to obtain the desired colour $X$, the arithmetic sum of the components is carried out: $X=R+G+B$, graphically represented by a cube-see Figure 2.

It is therefore understood that the development of sensors has benefited archaeological applications using phototogrammetry, such as the use of near-ultraviolet images [30] or aerial thermography [31]. Moreover, multispectral and hyperspectral satellite-based instruments have provided substantial data for the detection, mapping and investigation of archaeological locations all over the world [32]. At the end of the 20th century with the launch of IKONOS, the first commercial very-high-resolution satellite with a spatial 
resolution of $1 \mathrm{~m}$, a major improvement for archaeological research applications, was achieved $[33,34]$. In summary, with the digital revolution, images are less expensive, easier to process and the latest algorithms can work with a low-cost or standard camera.

The main objective of this research is to analyse global research trends in the application of photogrammetry to archaeology, as well as future lines of research. To this end, a bibliometric study of all indexed publications in these fields will be analysed and classified by means of a cluster analysis. As secondary objectives in addition, the periods in which significant advances in scientific production related to both fields have taken place, in which scientific categories these contributions can be classified, which are the main countries and institutions working in this field and their possible relationship with each other will also be sought.

Although there are no specific bibliometric studies in the literature on photogrammetry applied to archaeology, it is worth highlighting the works related to cultural heritage, which were searched in WoS (Web of Science), obtaining 535 records for the period from 1987 to 2007, and finding a significant increase in the number of publications since 2012. It is also concluded that tourism is the main driver of the digital transformation of heritage [35] and digital technology tools, such as 3D technology, laser technology, geographic information technology, database modelling, providing important tools for risk management, monitoring, planning and visualisation of cultural heritage [36]. In the analysis of the scientific communities that have been found are applications in archaeology, with related means of detection, such as laser scanning, radar, remote sensing or photogrammetry [37].

Later, a bibliometric study was carried out focusing on remote sensing and archaeology for the years 1999 to 2015, but limited to European countries [38]. They obtained 434 results. In this research, they found an increasing linear trend over time, i.e., they did not find periods of progress in scientific publication in this field. However, what is relevant for our research is that in the analysis of the evolution of the keywords, photogrammetry and digital photogrammetry have stood out since 2010, and in the last years studied, 2015, coastal archaeology and computer vision have appeared.

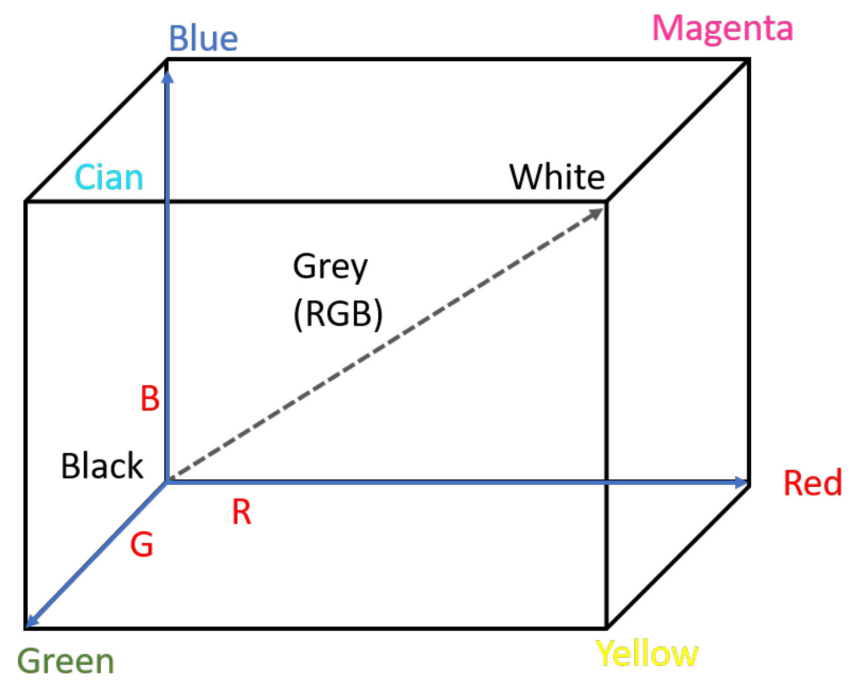

Figure 2. Relationship between greyscale and colors (RGB) of the photography.

\section{Materials and Methods}

There are two large scientific databases-Scopus, and WoS (Web of Science). Scopus has been proven to overlap in many scientific areas by a large percentage with WoS (Web of Science) [39,40], and has been successfully used for a large variety of bibliometric studies in specific areas such as medicine [41], social sciences [42] or engineering [43]. Therefore, Scopus has been used to conduct this research.

The query was: (TITLE-ABS-KEY (archaeology) AND TITLE-ABS-KEY (photogrammetry)). See Figure 3 for an overview of the methodology followed. The analysis of the 
scientific communities, both in terms of keywords and the relationship between authors or between countries, was executed with the software VOSviewer [44]. The problem of community detection arises from a common characteristic inherent to all complex systems. This characteristic is the presence of patterns of nodes that are more densely connected to each other than to the rest of the nodes in the network [45]. The nodes that show these connection patterns are called communities. From these, they are expected to share certain properties that will allow the detection of new characteristics or functional relations of the network [46]. The search for these patterns or community structures is known as the problem of community detection. To do so, the optimal community structure that best represents the characteristics of a network has become a scientific challenge. For this purpose, a multitude of algorithms and objective functions have been proposed to solve the problem. Among them, the evolutionary algorithms and the modularity index have stood out as the main solutions accepted by the scientific community [47]. The software tool Vosviewer uses an algorithm for modularity-based community detection in large networks. Modularity functions were introduced by Newman and Girvan, and the idea of using them to detect communities by optimizing a modularity function was proposed by Newman himself [48]. There are many variants of the modularity-based approach to community detection. These variants, for example, deal with targeted or weighted networks, or provide a resolution parameter [49] that allows for customization of the level of granularity at which communities are detected and mitigation of the so-called resolution limit problem [50]. For the case of the date trend, the keywords are associated with the date of publication; based on a date probability density function for a particular keyword, the maximum of the function is chosen to indicate the date where a particular keyword is most accumulated.

Note that as an alternative tool to the software used in this research, there is also a new open-source software tool, SciMAT, which performs scientific mapping analysis [51].

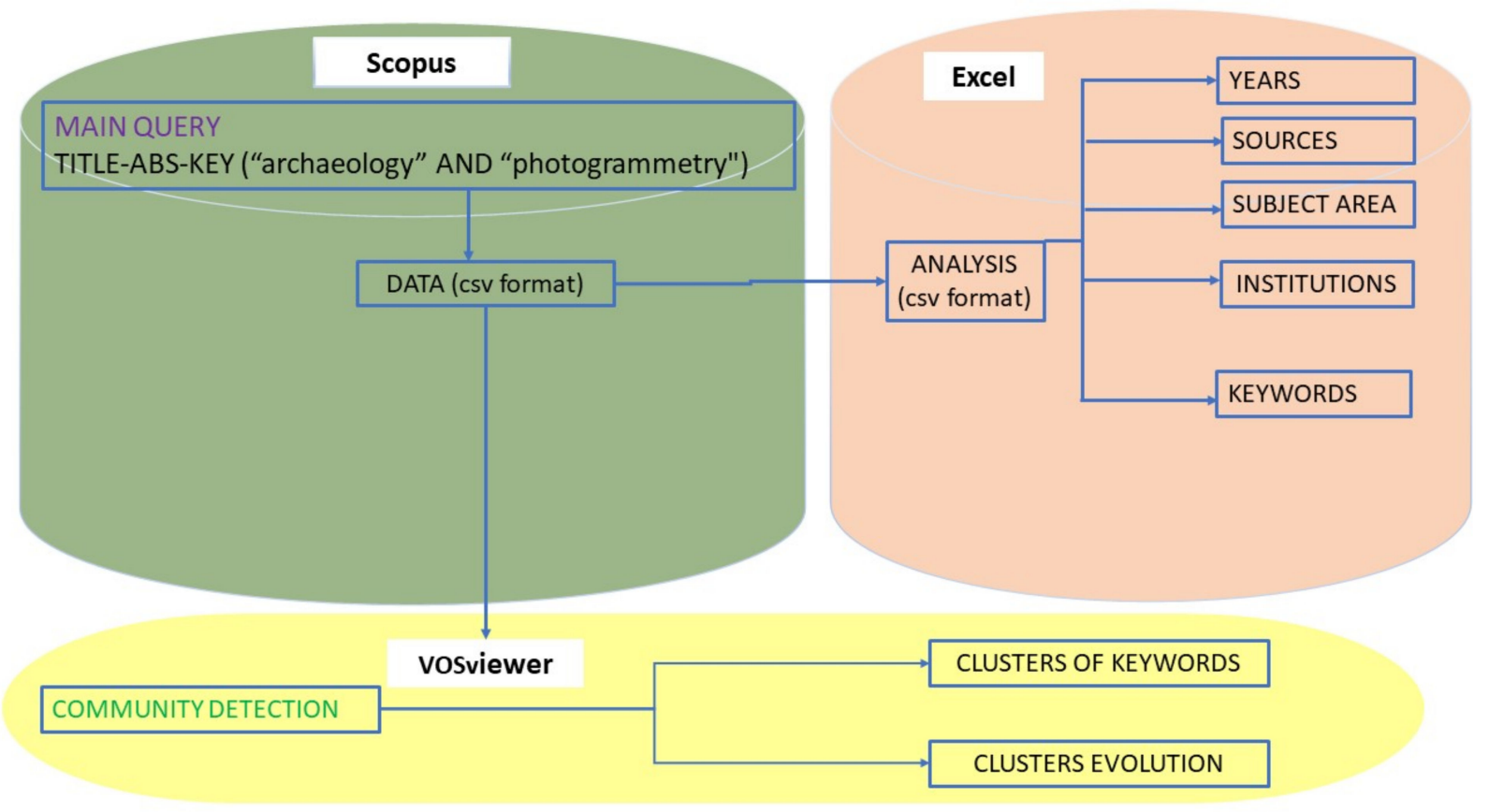

Figure 3. Methodology flow chart. 


\section{Results}

The search yielded just over 700 results in the studied period (1980-2019), of which $52 \%$ were in conference paper format, $43 \%$ were articles (of which $2.5 \%$ were review articles in this field), and just under $2 \%$ were books or book chapters. This is an indicator that this field of research is certainly new. The more consolidated the research, the higher the percentage of books, and articles, but when it is dominated by conference papers, the scientific field is still on the rise [52].

\subsection{Scientific Categories of Research in Photogrammetry and Archaeology}

When analyzing the results obtained by the scientific categories in which they are indexed according to Scopus (see Figure 4) it can be seen, as expected, that it is led by social science $(26 \%)$, where archaeology studies are partially included. Therein follow, almost at the same level, computer science (24\%), then arts and humanities $(12 \%)$, which is the most significant field of archaeology, and finally, the fields of earth and planetary sciences $(9 \%)$, which is where geomatics is traditionally included, and engineering $(8 \%)$. Other categories, as can be seen in Figure 4, are less relevant.

It should be noted that the same research can be indexed in several scientific categories at once. For example, a review on the use of drones (or UAV) to make 3D maps is outstanding [53]. This study deals with archaeology, but also with other sciences such as engineering since they propose that drones or UAVs can be considered as a low-cost alternative to conventional manned aerial photogrammetry.

However, other publications are indexed according to the journal, such as a case study of Mondújar castle (Spain) using UAV photogrammetry surveying for sustainable conservation [54] or the rockfall susceptibility analysis of the western slope of the Cumae Mount in the Cumae Archaeological Site (Phlegraean Fields, Naples, Italy) [55].

The computer science category, for example, includes further advances in image analysis techniques, such as automated reconstruction of 3D scenes from image sequences [56], or specific research on UAV systems and flight modes for photogrammetric applications [57]. This last category, computer science, has considerable overlap with engineering, in the line of research being analyzed. As an anecdote, other categories could be considered, such as energy, medicine, or decision science. This, as mentioned above, is the result of review articles that involve or cover all the fields of study where certain technology can be applied; i.e., the work is also indexed in these categories.

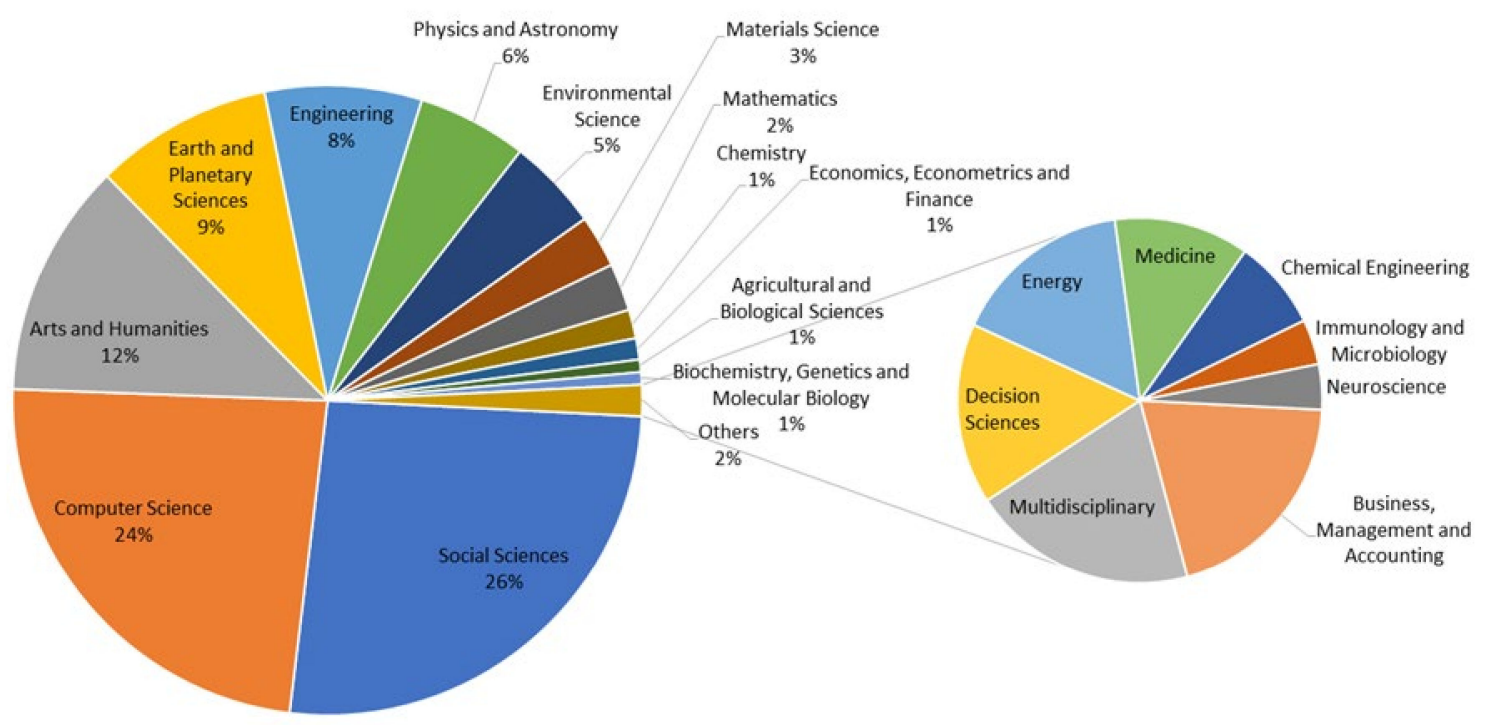

Figure 4. Distribution by scientific categories of research in photogrammetry and archaeology. 


\subsection{Temporal Evolution of the Publications}

Over time, the evolution of these works has been discontinuous until 1999 (see Figure 5), which we could describe as an approach of archaeology to photogrammetry. This can be explained by two factors: either the costs or the technology were not appropriate for its implementation or also from the bibliometric point of view, since in the last 20 years they have launched significantly more scientific journals that increase the number of published papers in all sciences.

The figure only shows the studies since 1980, since previously the scientific production of these photogrammetric and archaeological studies was very sparse in time. The first recorded study began in 1962 with "The Teotihuacan Mapping Project" in the Valley of Mexico [58], where the idea was to fly an area of $20 \mathrm{~km}^{2}$, although it was estimated that the site could more than double the area, about $53 \mathrm{~km}^{2}$.

This project is still a reference in the early days of photogrammetry for archaeology and is being studied $[59,60]$. After this work, a gap of almost a decade appears. As early as 1970, the Celtic fields in Himmerland were discovered through vertical photography on a scale of 1:25,000 (Denmark) [61], where an ancient Celtic cultivation pattern was found. This may be considered an example of the so-called aerial archaeology techniques, in which a large area of land is analysed using photogrammetry. Another closer example could be the Phoenician-Punic fortified settlement on the coast of eastern Andalusia called Altos de Reveque [62]. Without intending to enter an in-depth debate on this issue, the need for the use of photogrammetry in archaeological excavations was already established in the 1970s. In the beginning, photography was used in archaeology, instead of photogrammetric techniques, and therefore the results obtained lacked metric accuracy. To cite one author who stated "Archaeologists seem to be generally unaware that if they used a square scale for photographs of their sites, they would increase the value of the photographs as it would be possible to obtain photogrammetrically accurate plans from them" but it was also stated that "if the photograph is taken just for an excavation it can be expensive" [63]. It is this constraint on costs that has undoubtedly limited the widespread use of photogrammetry in archaeology over decades. However, there is clearly a constant and growing trend of documents with the issue of photogrammetry applied to archaeology in the last decade, from 2010 to 2019.

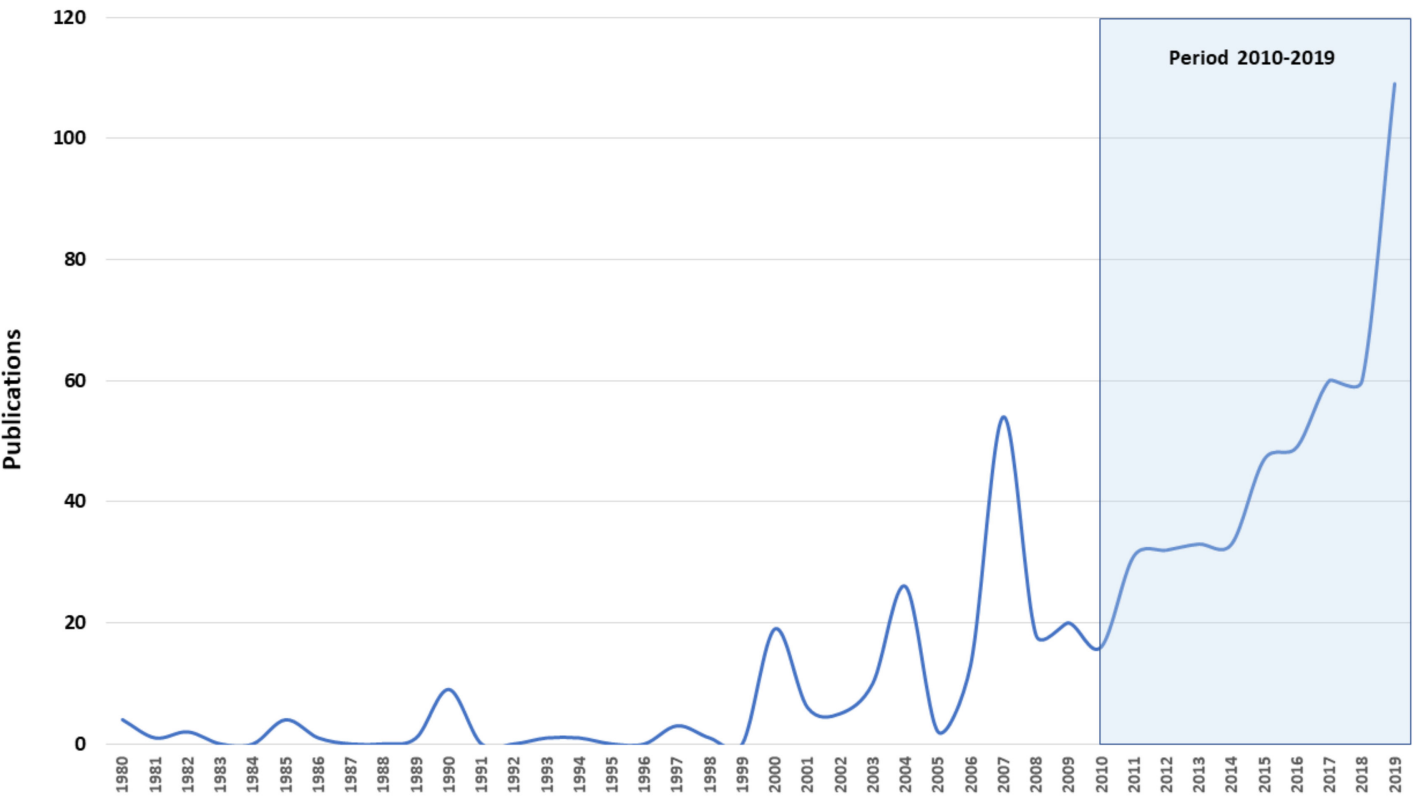

Figure 5. Temporal evolution of research in photogrammetry and archaeology. 


\subsection{Countries and Research Centres or Affiliations}

Publications focussed on photogrammetry and archaeology are mainly produced by central research institutions in France or Italy, see Figure 6. The colours of the figure just intend to highlight the first three positions of this ranking, where the red colour is the one that leads this classification with more than 30 publications, the CNRS Centre National de la Recherche Scientifique, and the yellow colour for the next two, which have more than 20 each, the Consiglio Nazionale delle Ricerche, and a Spanish university, the Universidad de Salamanca. The institutions with more than 20 publication in this field are shown in Figure 4. Regarding these studies, it should be noted that the French institution has an important interest in photogrammetry in underwater archaeology, such as the shipwreck of the Phoenician Xelendi in Malta [64], which is probably the oldest known shipwreck in the western Mediterranean. This line of research involves underwater photogrammetry in extreme conditions, for example, in high turbidity waters, such as the work carried out with the Roman wreck Arles-Rhone XIII in the Rhodano River (France) [65]; or in deep waters such as the ROV -D project which was responsible for the study of the Roman shipwreck Cap Bénat 4, at a depth of 328 m [66].

The Italian Consiglio Nazionale delle Ricerche, for its part, stands out in the virtual reconstruction applied to archaeology, for example in its territory such as that of some building in the city of Pompeii, Insula V 1, whose data were taken with laserscan [67], or international collaborations such as the reconstruction of a typical building called Huaca Arco Iris, located in the complex of the site of Chan, a UNESCO archaeological site in Peru [68].

Spanish research in the field of photogrammetry for archaeological applications, led by the University of Salamanca, is most successful in the use of drones or UAVs as an effective and low-cost tool [22]. One of the first works in this sense was in the archaeological modelling of a Jewish tannery in Avila [69].

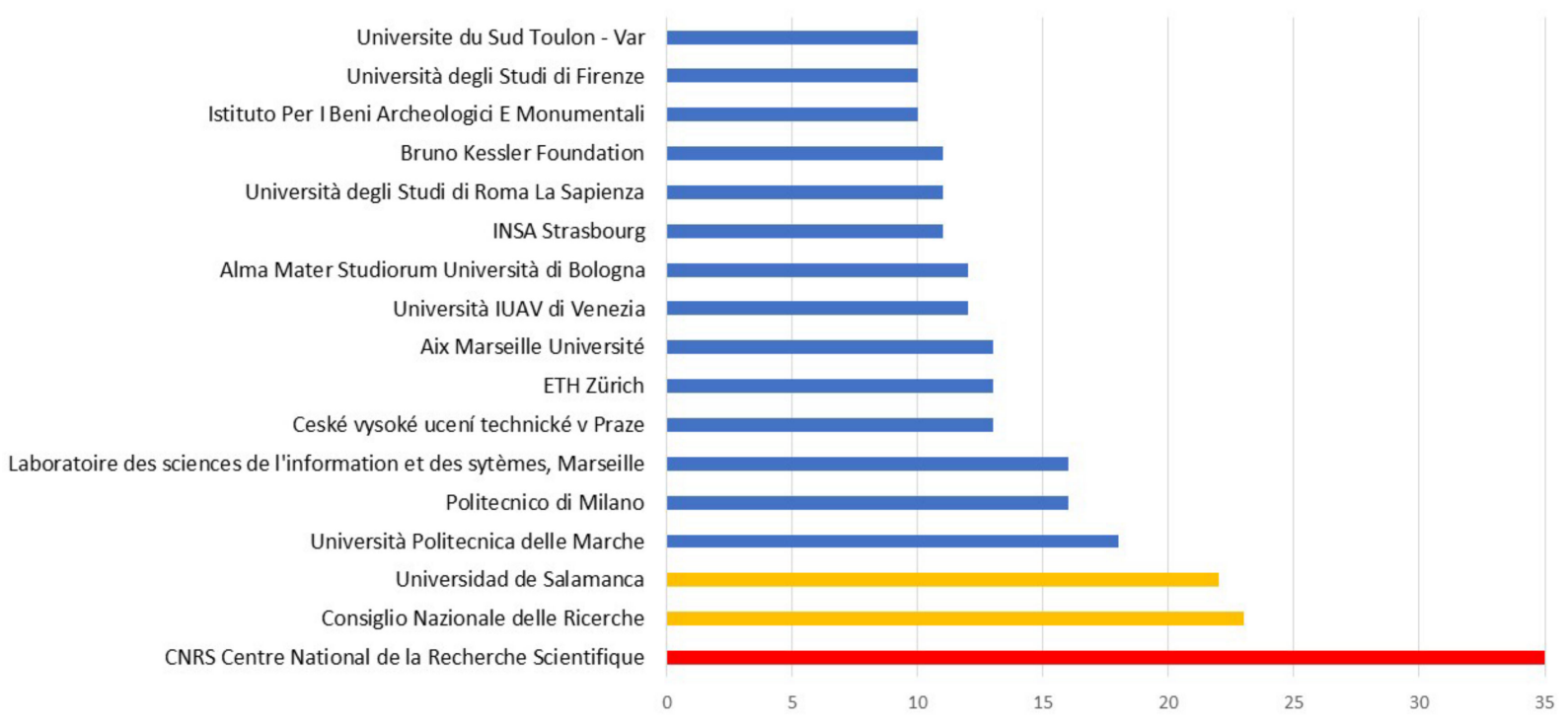

Figure 6. Major research affiliations in photogrammetry and archaeology.

If the publications by country are analysed, in general this line of research, as seen in the affiliations, is led by Italy with more than 180 works. Then there is another group of countries - the United States, Spain, France, and the United Kingdom - with a range of between 50 and 100 papers. The third group of countries, with publications between 21 and 50, would be Germany, Greece, Austria, and the Czech Republic. The geographical distribution of these publications is shown in Figure 7.

As one might expect, the United States has a long tradition in this regard. In fact, the first recorded work is from 1964, the Teotihuacan mapping project by Million [58]. This 
country stands out in the use of GIS within this line of research [70], innovating with 3D GIS [71] and 4D GIS [72], and recently exploring the possibilities of online platforms such as Google Earth in this field [73].

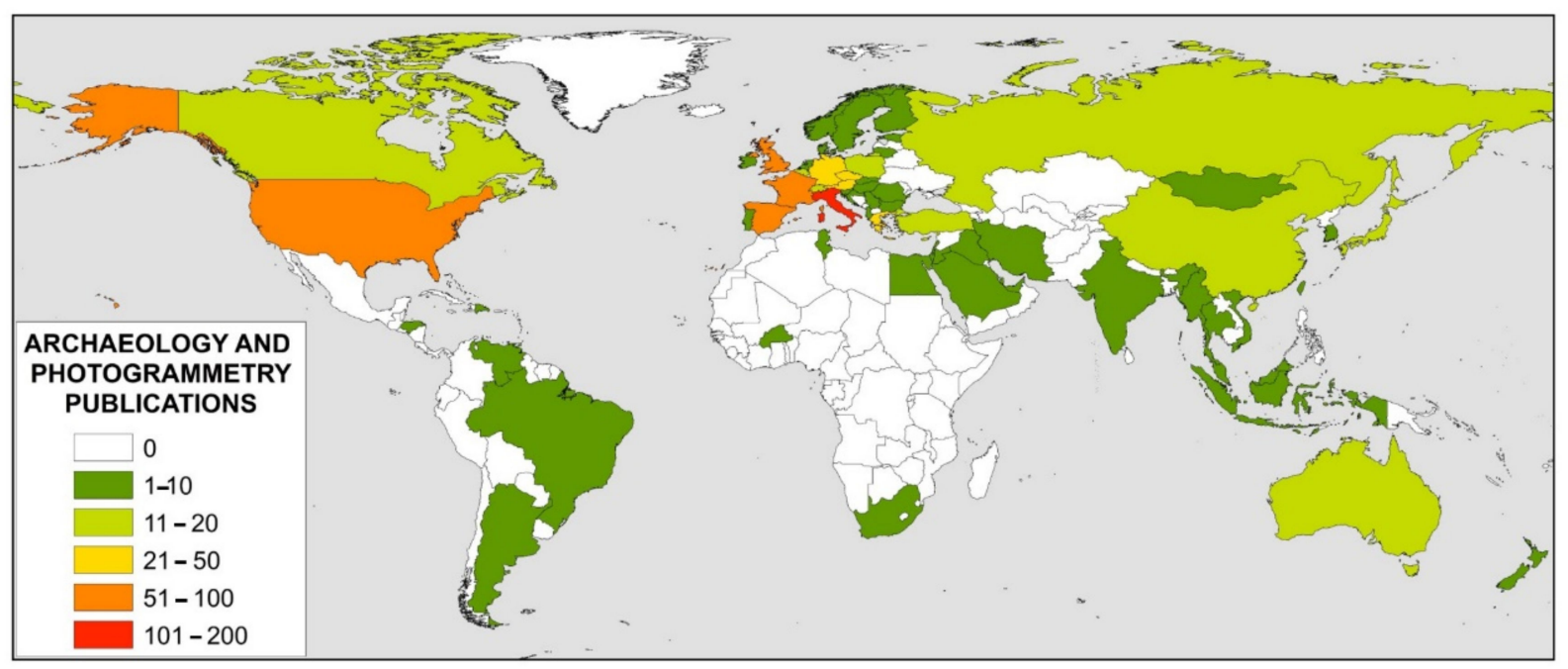

Figure 7. Distribution by country of research in photogrammetry and archaeology.

\subsection{Authors}

Concerning the main authors who have published in this field, Table 1 provides a detailed list of the top 10 authors with the most publications in this field. In the last column, their degree of specialisation in this subject has been established by comparing the author's total publications to date with those of the research topic.

It can be observed that one author has a high degree of specialisation, but this is due to the low number of total publications. From the list of authors, the first author, Pierre Drap, can be understood as a specialist in this field, since more than a third of his publications are in this field. The second in this ranking of specialisation is Francesco Guerra, with almost $25 \%$. The other authors in this list are around $10 \%$. It is remarkable that 6 of the top 10 authors are from France.

Table 1. Top 10 authors in photogrammetry applied to archaeology.

\begin{tabular}{ccccc}
\hline Author & Affiliation, Country & $\mathbf{N}_{\mathbf{T}}$ & $\mathbf{N}_{\text {Ph\&A }}$ & $\mathbf{\%}$ \\
\hline $\begin{array}{c}\text { Drap, Pierre } \\
\text { González-Aguilera, }\end{array}$ & Aix Marseille Université, France & 67 & 23 & 34.3 \\
Diego & Universidad de Salamanca, Spain & 197 & 12 & 6.1 \\
Seinturier, Julien & COMEX SA, France & 17 & 12 & 70.6 \\
Guerra, Francesco & Università IUAV di Venezia, Italy & 45 & 11 & 24.4 \\
Pavelka, Karel & Ceské vysoké ucení technické v Praze, & 86 & 10 & 11.6 \\
Grussenmeyer, Pierre & Czech Republic & 128 & 9 & 7.0 \\
Nocerino, Erica & INSA Strasbourg, France & 82 & 9 & 11.0 \\
Menna, Fabio & Aix Marseille Université, France & 69 & 8 & 11.6 \\
Merad, Djamal & COMEX SA, France & 57 & 8 & 7.0 \\
Rodríguez-Gonzálvez, P. & Aix Marseille Université, France & 108 & & 7 \\
\hline
\end{tabular}

Figure 8 analyses the scientific collaboration between all the authors who have published in this field, some 167. It can be seen that there are six groups of authors, which are listed in Table 2, where the affiliation of the main author of that cluster has been highlighted in the first column. In the last column, the main lines of research of the cluster have been 
detailed according to the keywords of their publications. Figure 9 shows the evolution of these scientific collaborations over time. Scientific collaboration in this field has been detected starting in 2008 from the institutions of Politecnico di Torino (Italy) and ETH Zürich, Zurich (Switzerland).

Table 2. Photogrammetry applied to archaeology: Research clusters.

\begin{tabular}{|c|c|c|c|}
\hline Cluster & Colour & Authors & Main Topics \\
\hline $\begin{array}{l}\text { Università IUAV di Venezia, } \\
\text { Venice, Italy }\end{array}$ & red & $\begin{array}{c}\text { Guerra F.; Balleti C.; Beltrame } \\
\text { C.; Costa E.; Vernier, P. }\end{array}$ & $\begin{array}{l}\text { photogrammetry; } 3 \mathrm{~d} \text { modelling; } \\
\text { cultural heritage; maritime } \\
\text { archaeology }\end{array}$ \\
\hline $\begin{array}{l}\text { Politecnico di Milano, Milan, } \\
\text { Italy }\end{array}$ & purple & Adami, A.; Fassi, F.; Rossi, C. & cultural heritages; laser scanner \\
\hline $\begin{array}{c}\text { Aix Marseille Université, } \\
\text { Marseille, France }\end{array}$ & green & $\begin{array}{c}\text { Nocerino, E.; Menna, F.; } \\
\text { Remondino, F.; Neyer, F.; } \\
\text { Gruen, A. }\end{array}$ & $\begin{array}{l}\text { photogrammetry; three } \\
\text { dimensional; computer graphics; } \\
\text { 3d modelling }\end{array}$ \\
\hline $\begin{array}{c}\text { Cyprus University of } \\
\text { Technology, Limassol, Cyprus }\end{array}$ & yellow & $\begin{array}{c}\text { Skarlatos, D.: Agrafiotis, P.; } \\
\text { Demesticha, S.; }\end{array}$ & $\begin{array}{l}\text { archaeological site; three } \\
\text { dimensional; computer graphics; } \\
\text { underwater photogrammetry }\end{array}$ \\
\hline $\begin{array}{l}\text { Politecnico di Torino, Turin, } \\
\text { Italy }\end{array}$ & blue & $\begin{array}{l}\text { Chiabrando, F.; Bornaz, L.; } \\
\text { Nex, F.; Rinaudo, F.; Spanò, A. }\end{array}$ & $\begin{array}{l}\text { archaeology; photogrammetry; } \\
\text { image acquisition }\end{array}$ \\
\hline $\begin{array}{c}\text { ETH Zürich, Zurich ZH, } \\
\text { Switzerland }\end{array}$ & cyan & Eisenbeiss, H.; Sauerbier, M. & $\begin{array}{l}\text { photogrammetry; archaeology; } \\
\text { archaeological excavations }\end{array}$ \\
\hline
\end{tabular}

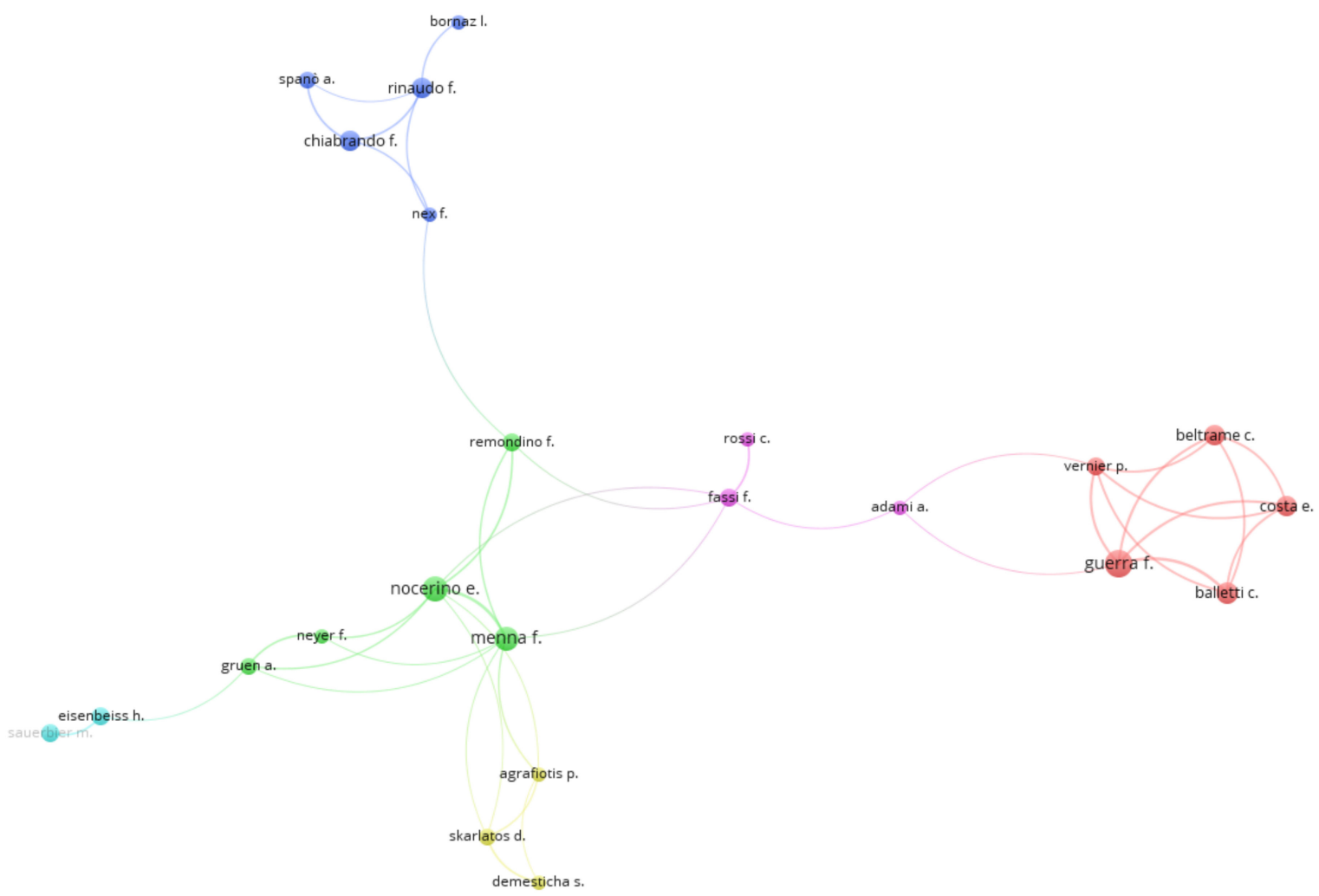

Figure 8. Scientific collaboration between all the authors in photogrammetry and archaeology. 


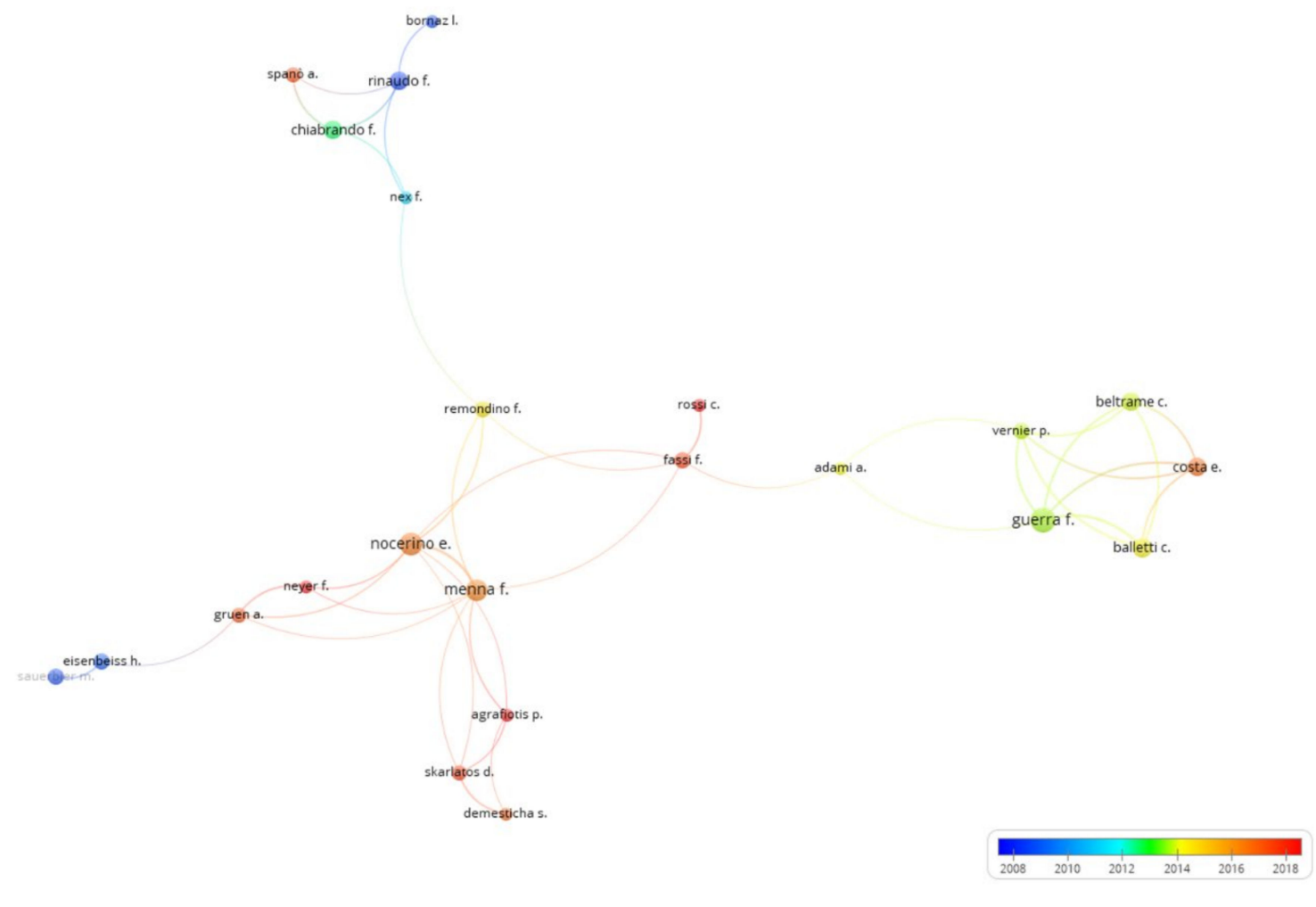

Figure 9. Evolution of Scientific collaboration between all the authors in photogrammetry and archaeology.

\subsection{Keyword Analysis}

In the publications studied, the lines of research in particular are defined by the indexing keywords. Figure 10 shows a cloud of words with all the key words in these publications, where the size is representative of the frequency of occurrence. If the search terms photogrammetry and archaeology are not taken into account, the most prominent keywords are: history (120 times), surveys (120 times), three dimensional computer graphics (117 times), remote sensing (115 times), cultural heritage (114 times), architecture (80 times), digital photogrammetry (65 times), laser applications (59 times), laser scanning (58 times), close range photogrammetry (56 times), excavation (55 times), 3d modeling (54 times), archaeological site (52 times), image reconstruction (51 times), visualization (51 times), or GIS (50 times).

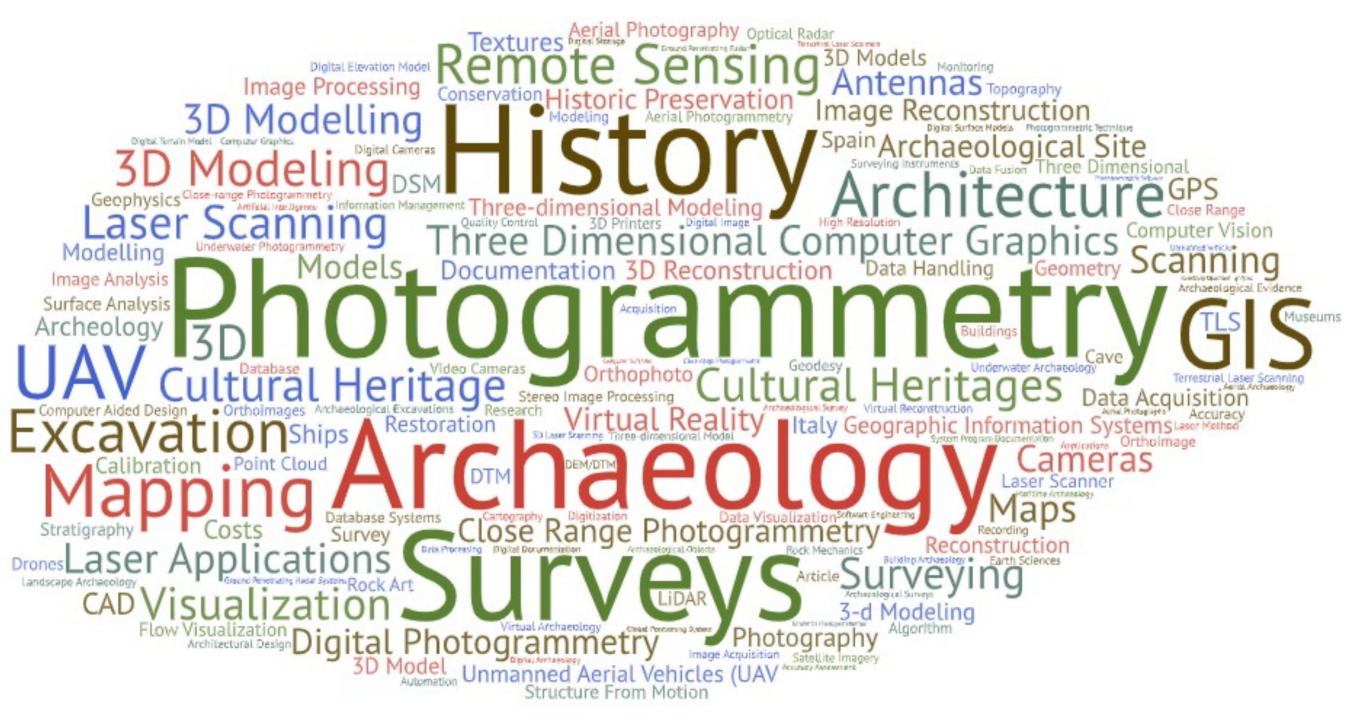

Figure 10. Cloud of words made with the keywords of research in photogrammetry and archaeology. 
The evolution of this research from the analysis of its keywords can be seen in Figure 11, and in Table 3. It began by focusing mainly on cartography (maps) and CAD systems in 2008, then in 2010 this information was integrated into GIS, virtual reconstruction was carried out, and it was proposed as a tool for cultural heritage [74]. Later, in 2012, 3D graphics were made, and scanners were used. In 2014, UAV flights and LiDAR systems were combined to make 3D reconstructions. It can be understood that this is where the jump is, i.e., the massive appearance of drones or UAVs. Figure 3 also shows a much higher growth rate than in previous periods. The last period in which they are still in use would be the SfM techniques and their application to what is called virtual archaeology and their application to building archaeology.

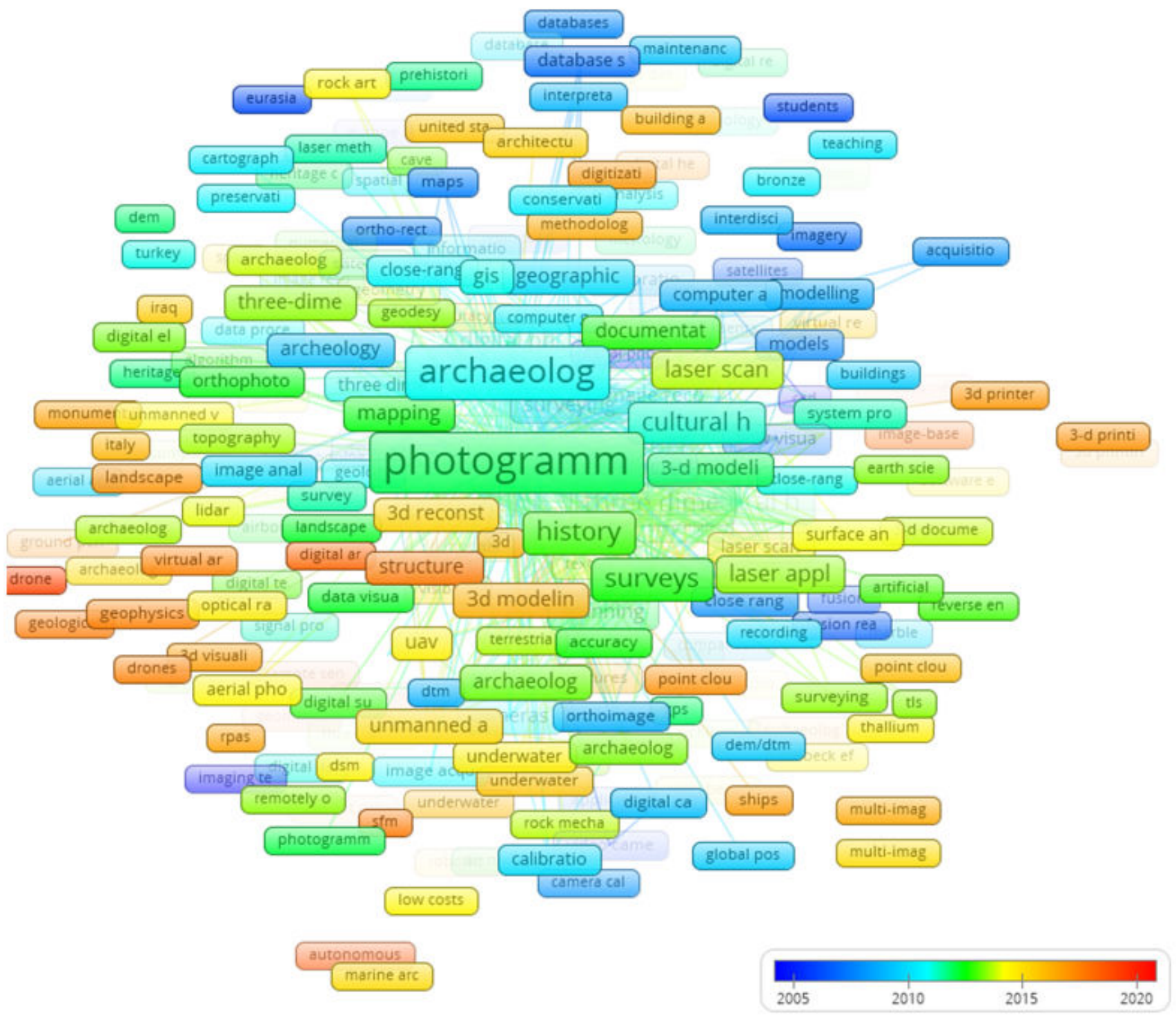

Figure 11. Research evolution in photogrammetry and archaeology in terms of keywords. 
Table 3. Evolution of keywords in photogrammetry applied to archaeology.

\begin{tabular}{cc}
\hline Year & Keywords \\
\hline 2008 & Maps, data base systems, computer aided design modelling \\
2010 & Cultural heritage, image reconstruction, GIS \\
2012 & Three-dimensional computer graph, mapping, scanning \\
2014 & UAV, LiDAR, 3D reconstruction \\
2016 & Structure from Motion, SfM, virtual archaeology, building archaeology \\
\hline
\end{tabular}

Figure 12 analyses the research relations between these countries and their evolution over time. This evolution or use of photogrammetry in archaeology, Figure 12, seems to have been started by Germany, Greece, and Japan in 2008. In a second period, France and the USA are incorporated in 2013, finally Italy, and more recently, Spain in 2015, as significant countries for the number of scientific contributions in this field. Modern UAVs include a GPS system with RTK on board, making the images already georeferenced. For this reason, a base station is established that retransmits differential corrections to the $\mathrm{UAV}$, and the images are already georeferenced as the center of capture of each photograph has precise coordinates. However, the use of UAVs for professional activities is subject to specific restrictions by law. This issue should therefore be dealt with due caution. In any case, the use of GPS for photogrammetric control points or ground control points (GCP) is fully accepted by the scientific community, both in terms of cost and accuracy [75].

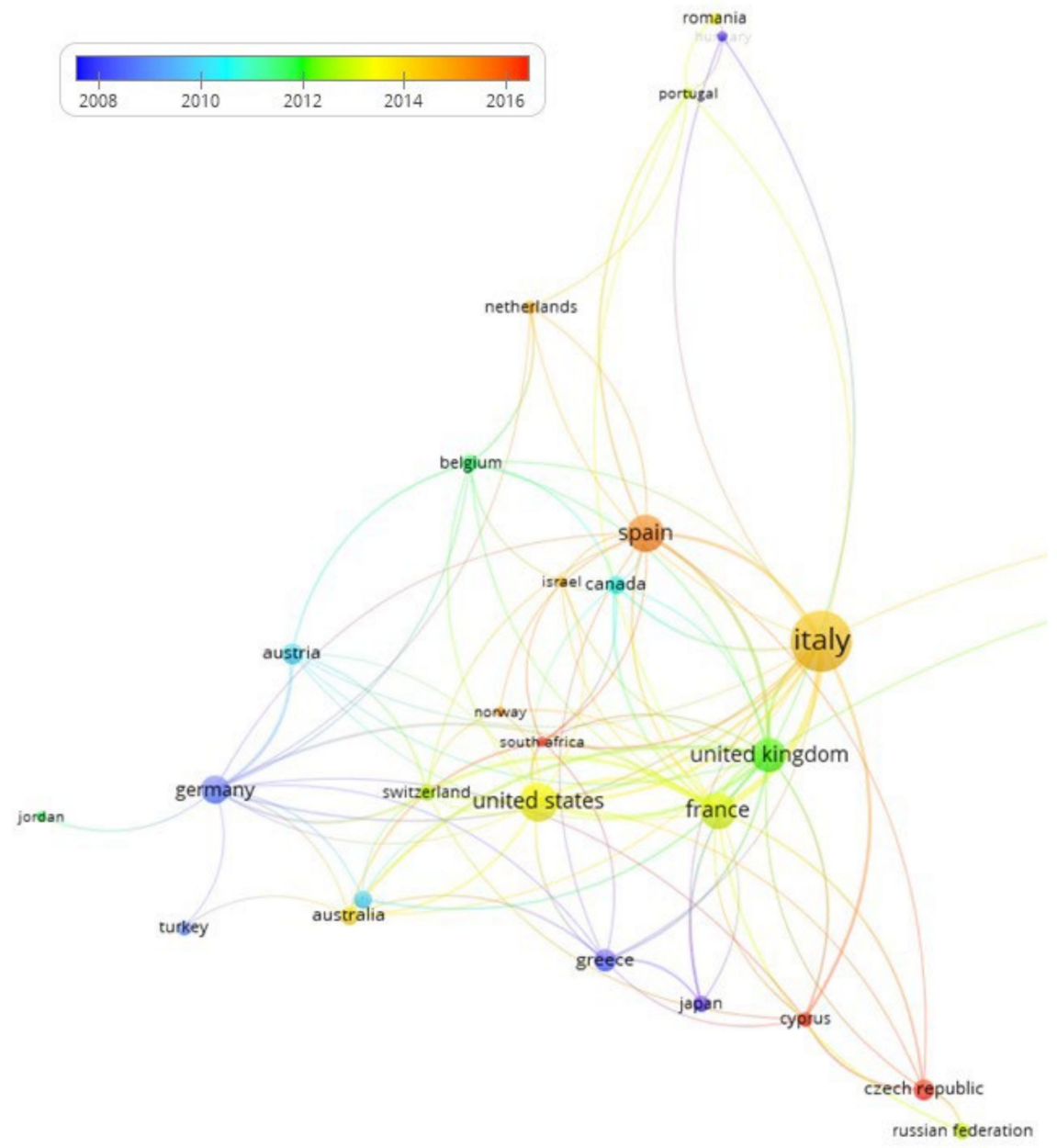

Figure 12. Evolution by country of research in photogrammetry and archaeology in terms of keywords. 


\section{Discussion: Research Trends in Photogrammetry Applied to Archaeology}

Finally, the analysis would not be complete without analyzing the scientific communities or clusters around which the line of research is conducted, which set the global research trends. To this end, the clusters obtained from all these publications are analysed with the free software VosViewer, which has given good returns in many scientific areas [76]. Figure 13 shows the eight clusters obtained, and Table 4 summarises them, naming them according to the main keywords obtained. Thus, the clusters obtained are those related to: terrestrial photogrammetry; aerial photogrammetry; cultural heritage; excavation; cameras; GPS; LaserScan; and virtual reconstruction/3D printers.

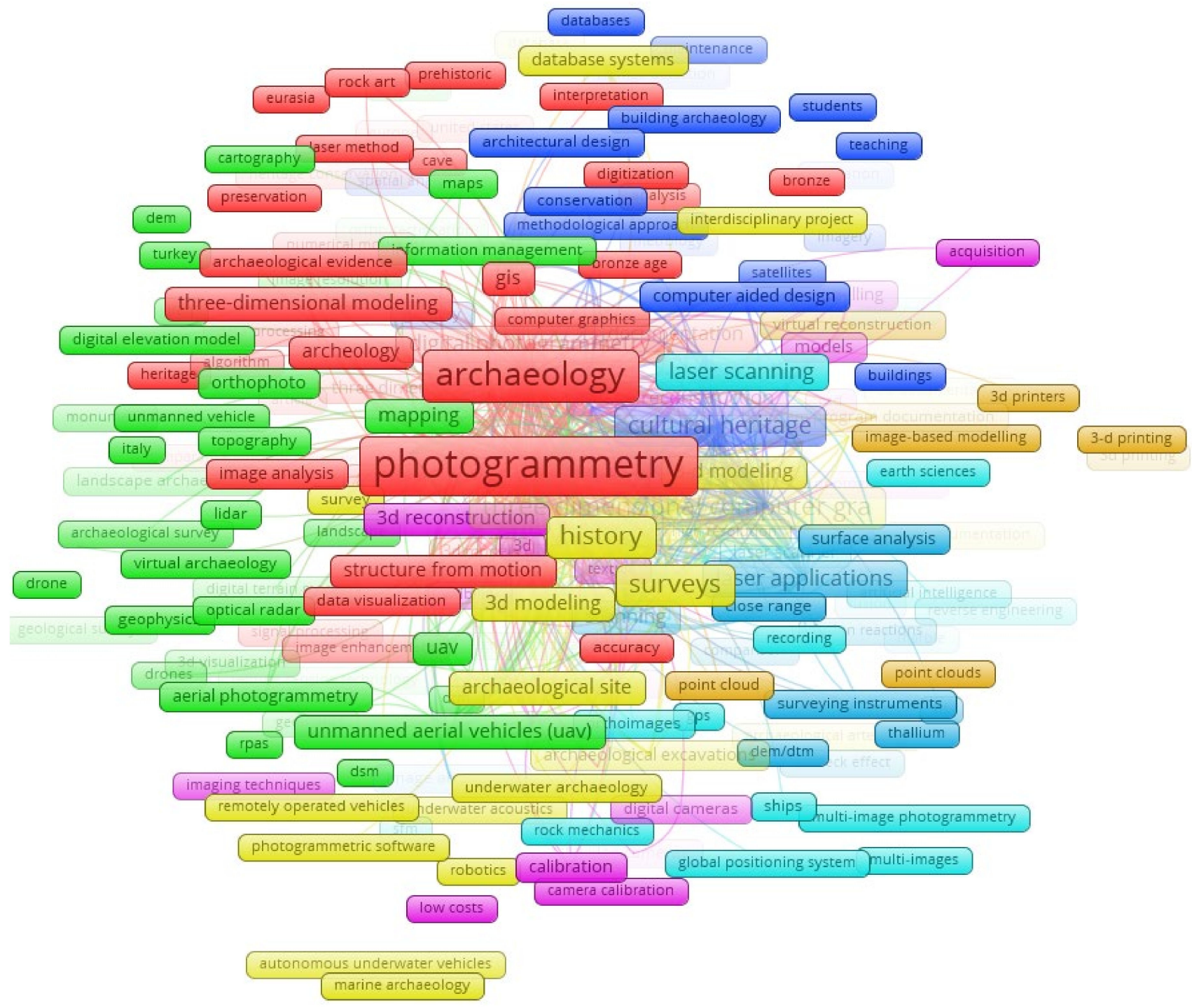

Figure 13. Clusters of research in photogrammetry and archaeology. 
Table 4. Photogrammetry applied to archaeology: Research clusters.

\begin{tabular}{|c|c|c|c|}
\hline Cluster & Weight (\%) & Color & Keywords \\
\hline $\begin{array}{c}\text { Close range } \\
\text { photogrammetry }\end{array}$ & 22.1 & red & $\begin{array}{l}\text { digital photogrammetry, three-dimensional modelling, } \\
\text { close range photogrammetry, structure from motion, 3D } \\
\text { models, GIS }\end{array}$ \\
\hline Aerial photogrammetry & 20.4 & green & $\begin{array}{c}\text { orthophoto/orthoimage, LiDAR, UAV, aerial } \\
\text { photography, remote sensing, mapping, Digital } \\
\text { elevation models }\end{array}$ \\
\hline Cultural heritage & 13.7 & blue & $\begin{array}{c}\text { Cultural heritage, architecture, buildings, geographic } \\
\text { information systems, computer aided design, historic } \\
\text { preservation }\end{array}$ \\
\hline Excavation & 12.6 & yellow & $\begin{array}{c}\text { Three-dimensional computer graph, history, excavation, } \\
\text { cost effectiveness, surveys, 3D modeling }\end{array}$ \\
\hline Cameras & 10.9 & purple & $\begin{array}{c}\text { 3D reconstruction, stereo image processing, CAD, } \\
\text { camera calibration, cameras }\end{array}$ \\
\hline GPS & 8.8 & cyan & $\begin{array}{c}\text { GPS, 3D modelling, reverse engineering, ground control } \\
\text { point, SfM, laser scan }\end{array}$ \\
\hline Laser scan & 7.7 & orange & $\begin{array}{l}\text { Laser applications, surface analysis, terrestrial laser } \\
\text { scanning, TLS, survey instruments }\end{array}$ \\
\hline $\begin{array}{l}\text { Virtual reconstruction } / 3 \mathrm{D} \\
\text { print }\end{array}$ & 3.9 & brown & $\begin{array}{l}\text { 3D printing, 3D printers, image-based modelling, point } \\
\text { cloud, virtual reconstruction }\end{array}$ \\
\hline
\end{tabular}

Cluster 1 is centered on near or short-range object photogrammetry. Of the first works in this sense, it is worth mentioning the study of the Mausoleum of the Emperor Qin Shi Huang in 1990, where techniques of close-range photogrammetry, low-altitude photogrammetry and remote sensing were combined [77]. However, it was not until years later, in 2000, that the use of close-range photogrammetry proved its use in virtual reality and its integration into archaeology [78]. It was this year that the close-range photogrammetric technique was used for the documentation of Naqsh-I Rustam in the south of Iran [79]. After this, there have been many success reports widely cited in the literature, such as the archaeological site of Ajina Tepa (Tajikistan) [80], the Upper Palaeolithic Cave of Parpalló (Spain) [81], or also the Bronze Age cave "Les Fraux" at Saint-Martin-de-Fressengeas (France) [82]. Figure 14 shows an example of close-range photogrammetry and 3D virtual reconstruction of an amphora from the 8th century BC, which is currently in the Archaeological Museum of Seville (Spain).

Cluster 2 focuses on aerial photogrammetry and the development of UAVs. A remarkable fact that could be considered as the beginning of UAVs is the work of Theodoridou et al., [83], on the use of remote-controlled helicopters for their application in archaeological studies and in the building construction industry. The idea was to create a system for acquiring photogrammetric images at low altitude, using a radio-controlled helicopter, and to develop a specific methodology based on digital photogrammetry, for the rapid and efficient survey of archaeological sites, excavations and/or monuments in general. It is noteworthy that in 2003 the use of hot air balloons (inflated with helium) was still being considered as a solution for the acquisition of images at low cost compared to traditional flights. Here, with 4 Megapixel cameras, an aerial image accuracy of better than $4 \mathrm{~cm}$ in position and height was achieved [84]. The first important work with UAVs can be said to have begun with the comparison of the DSM (digital surface model) generated from images of mini-UAVs and terrestrial laser scanners in cultural heritage applications. For example, the studies of Pinchango Alto, an LIP settlement (Late Intermediate Period; 1400 AD), located $400 \mathrm{~km}$ south of the capital of Peru (Lima), near the famous Nasca geoglyphs, where they achieved $10 \mathrm{~cm}$ resolution with UAV images [85]. A 3D comparison of both elevation models shows an average value of less than $1 \mathrm{~cm}$ with a standard deviation of $6 \mathrm{~cm}$. LiDAR (laser imaging detection and ranging) systems have demonstrated a high capacity to rapidly produce digital terrain models (DTMs) even under vegetation. This in archaeology has meant a very important progress in the prospection of large territories 
scarcely explored due to orographic or vegetation difficulties. As early examples, there are the studies in Ireland on the abandoned medieval settlement of Newtown Jerpoint, the prehistoric port of Dún Ailinne or the archaeological complex of Tara Hill [86]. Another work of interest in this sense was in the archaeological zone of Augusta Bagiennorum, where different surveys have been carried out since 1990. With UAVs flying at an altitude of $200 \mathrm{~m}$ with an average speed of $15 \mathrm{~m} / \mathrm{s}$, they obtained the accuracy of three-dimensional mapping suitable for determining the suitability of this technique for archaeological purposes [87]. Figure 15 shows a UAV photogrammetric flight of Utica (Tunisia) in the year 2018 under the research started by the Tunisian-Spanish project launched in 2010 [88].
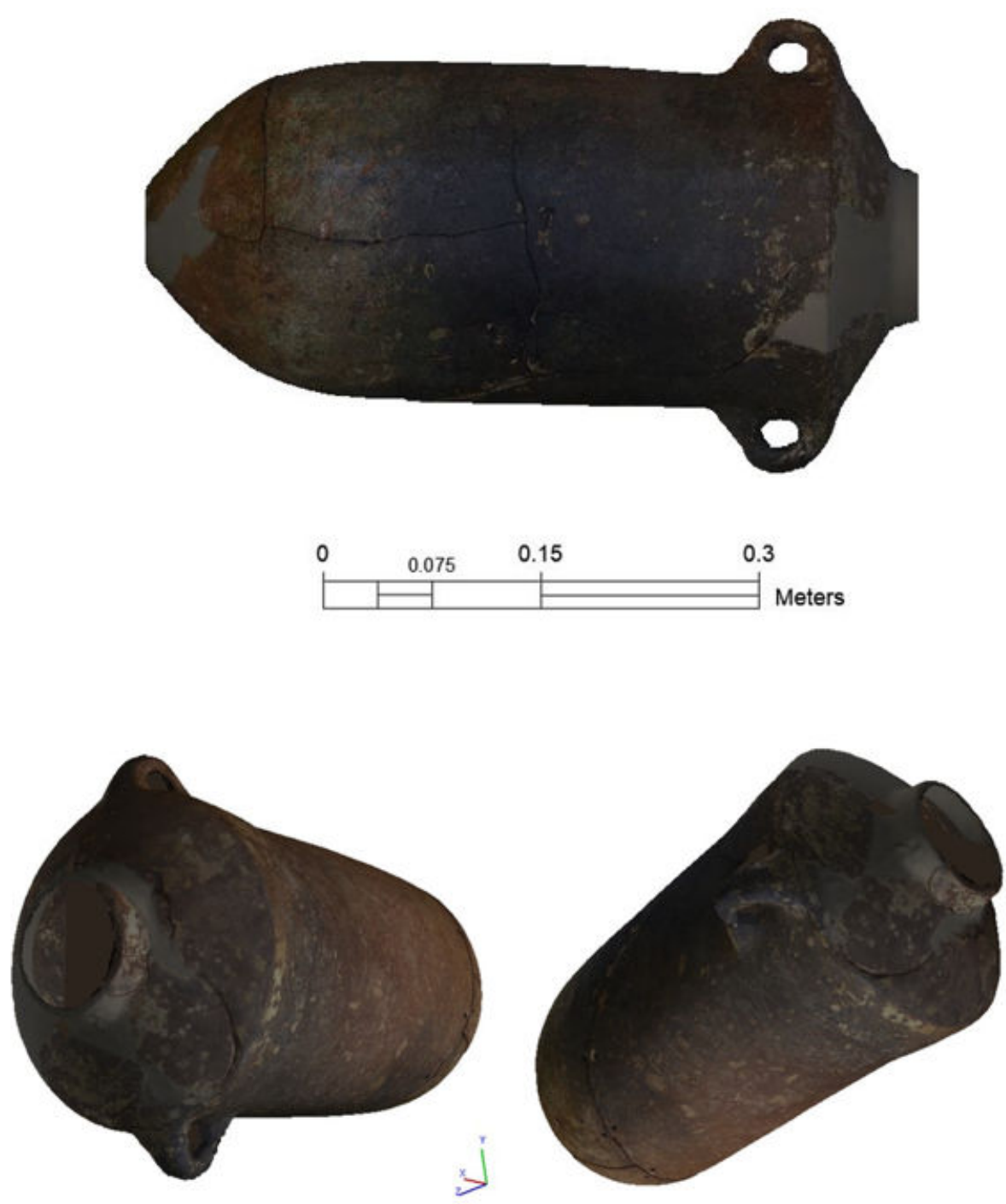

Figure 14. Close range photogrammetry and 3D virtual reconstruction. 

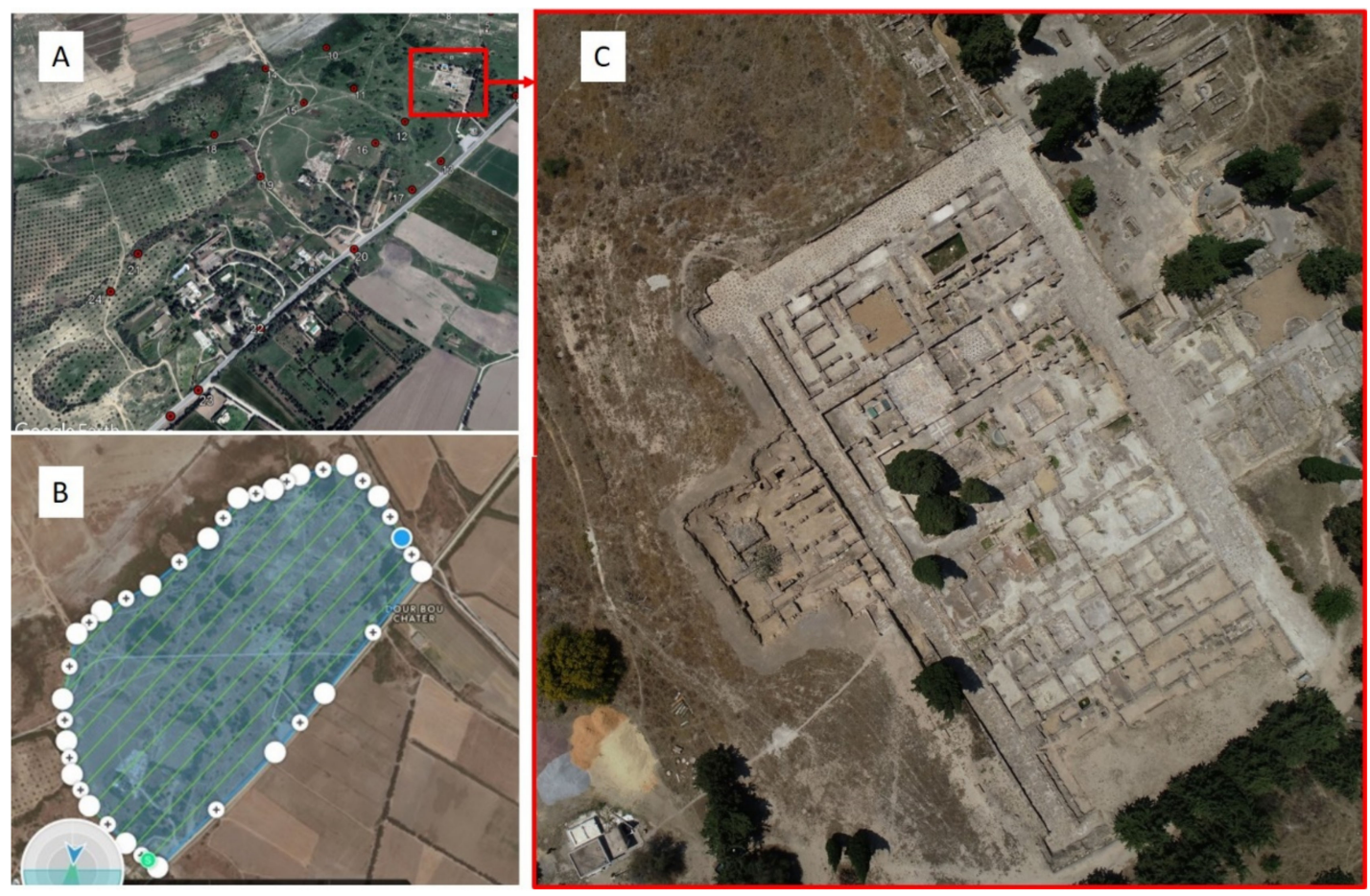

Figure 15. UAV photogrammetric flight of Utica (Tunisia). (A) Ground control points. (B) Photogrammetric flight paths. (C) Example of aerial photography on the restored Roman insula.

Cluster 3, named cultural heritage, is closely linked to virtual reality and 3D modelling [89]. An example is the integration of different topographical and photogrammetric survey methods, together with photographic virtual reality techniques, around the ancient city of Bakchias (Fayyum, Egypt) [90]. The great potential of virtual reality technologies is that they make it possible to study an archaeological site from remote locations using the Internet without the need for people to travel. In addition, the 3D reconstruction allows you to move from a 3D model to a 2D model for your study. An outstanding example is the large hypostyle hall of the Karnak temple [91], where, by means of photogrammetry, they made it possible to study and record the hieroglyphic inscriptions engraved on conical or cylindrical surfaces. This study carried out a three-dimensional reconstitution of a column and a two-dimensional survey of its epigraphy, based on a series of snapshots of the column's surface. Figure 16 shows a 3D image of parts of a temple, city of Utica (Tunisia), from several point of view.

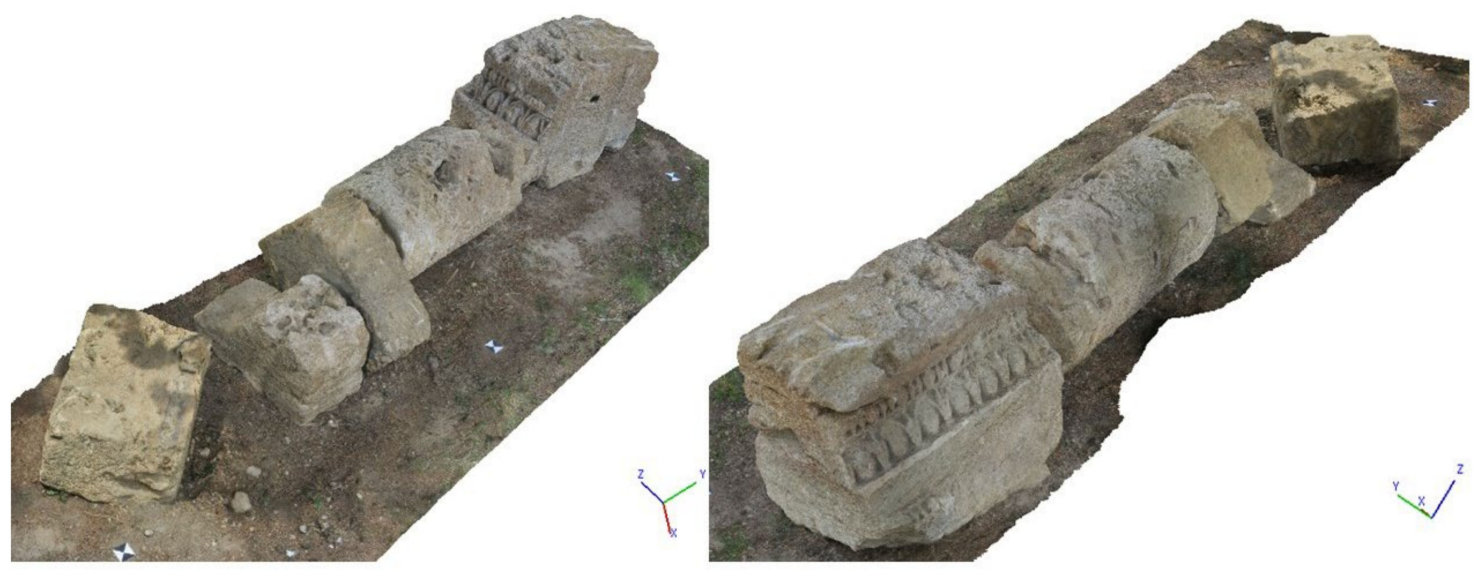

Figure 16. Image $3 \mathrm{D}$ showing parts of a temple, city of Utica (Tunisia). 
Cluster 4 has been named the excavation cluster. Here, the aim is to bring together all the techniques - for example, combining various data sources such as 3D tachometric surveys and photogrammetry. An early example is the Finnish mission at Jabal Haroun (Mount Aaron) in Petra, Jordan [92]. Already, many authors suggest that for excavations, UAVs can be a suitable alternative to traditional measuring methods such as tape measures or tachymeters [93]. These authors made three case studies of different lengths: a large archaeological site in Bhutan, the excavation of a smaller site containing ancient tombs in the Nasca region (Peru) and the Mayan site of Copan (Honduras). For example, in Spain, comparative studies have been carried out at the excavation level, between terrestrial laser scanning (TLS) and close-range photogrammetry - for example, in the cave of Can Sadurní (Begues, Barcelona) which is a Neolithic burial episode [94]. Another example is in the urban archaeological site of Plaza Velarde in Santander, which is an area of $450 \mathrm{~m}^{2}$; to document all the structures that appeared in the archaeological site, it was decided to use photogrammetry techniques from digital camera images taken from a UAV [95]. Figure 17 illustrates the photogrammetry for the archaeological excavation site in the city of Utica. The Figure 18 shows how the 3D reconstruction allows you to rotate to study it from different points of view.
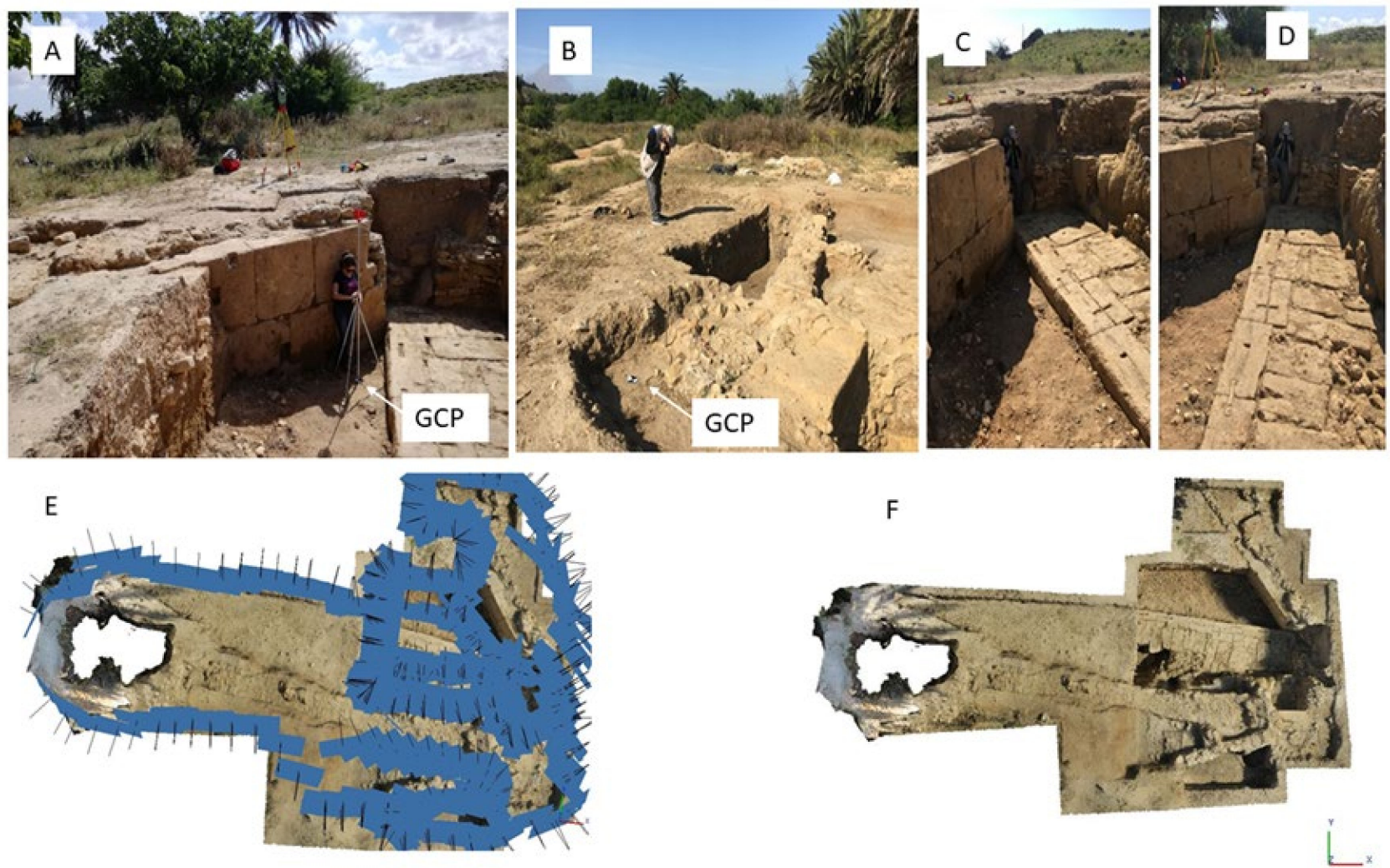

Figure 17. Photogrammetry for the archaeological excavation site in the city of Utica (Tunisia). (A) The survey of control points with total station; (B-D) the recording of photographs with a conventional camera from different points of view; (E) the points of view of all the photographs taken; (F) the final 3D model obtained. 


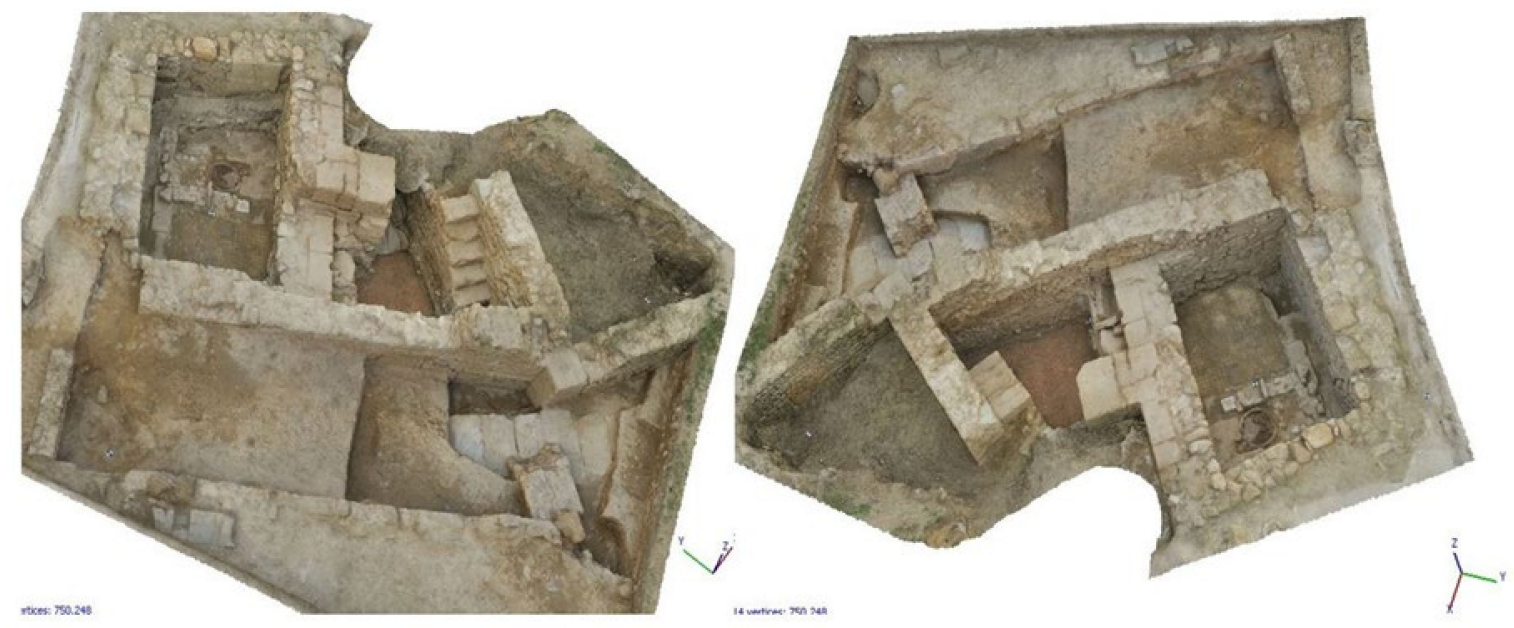

Figure 18. 3D reconstruction of an archaeological excavation site in the city of Utica (Tunisia).

Cluster 5 is dedicated to cameras, and therefore it is understood that it is more in the field of computer science or engineering than of archaeology itself, although it has a clear application to this field. Photogrammetry usually requires calibrated metric cameras so that the whole process of internal orientation can be carried out, and the alternative steps of external orientation of each data acquisition, and relative and absolute orientation. The three-dimensional reconstruction of scenes from uncalibrated images is one of the most technically difficult problems in computer vision and photogrammetry [96]. So, camera self-calibration is an important research topic in computer vision [97]. Only images taken from different locations and orientations are available to estimate the intrinsic camera parameters. By using only these images, the relationship between pairs of images can be represented algebraically with fundamental matrices. However, the fundamental matrix contains both the intrinsic camera parameters and the relative motion between the two images or cameras. Therefore, a formulation must be defined that does not change due to the relative motion between the two images. Due to this contradictory relationship, there must be a virtual conic that is far enough away from the camera while viewing the locations, and its projection depends only on the intrinsic parameters of the camera. By defining the relationship between this virtual conic and the intrinsic parameters of the camera, the equations for the self-calibration of the camera are defined [98]. The development of these systems or algorithms has made it possible to use unknown camera settings (uncalibrated cameras), and even to change the parameters of this camera, such as zoom or focus during the data acquisition. This line of work then focuses on systems that automatically extract a textured 3D surface model from a sequence of images of the same scene.

Cluster 6 is focused on GPS. Above all, it should be noted that in large extensions of land the establishment of control points for photogrammetric flights with UAVs or the integration of archaeological sections requires georeferenced data (see example in Figure 19), so that all the information can be integrated into a GIS and subsequently analyzed [99]. 


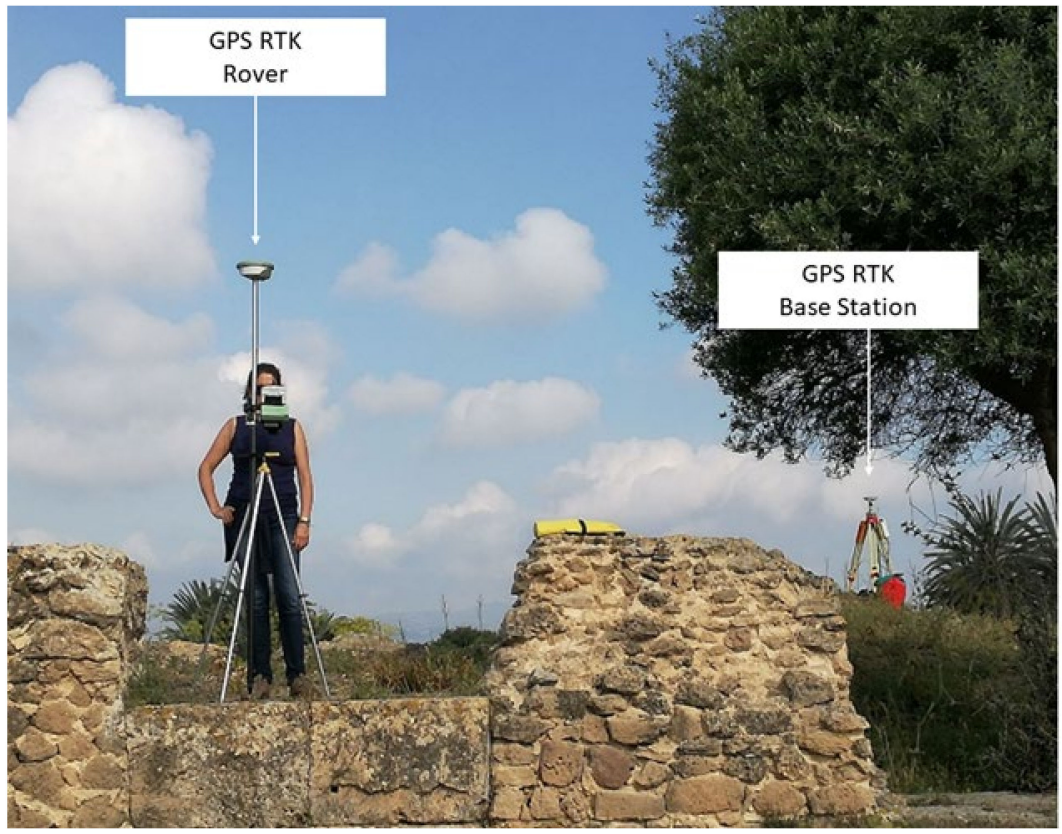

Figure 19. Measurement of control points with GPS RTK for photogrammetric flight in the city of Utica (Tunisia).

Cluster 7 focused on instrumentation, especially terrestrial laser scanners (TLS). Terrestrial laser scanning has become increasingly popular in recent years as it provides very dense 3D points on the surface of an object with high accuracy [100]. These techniques have been combined with others as mentioned above, such as with UAV [101].

As an anecdote, it is worth mentioning that quite a few works from the so-called "industrial archaeology" are included in this cluster. Without intending to make a debate on the question, it results in the indexing of many papers with this search term within archaeology. Industrial archaeology is concerned with questions of industrial culture and the preservation of industrial monuments [102,103] or best-known historical inventions [104]. The concept was introduced in 1955 in England, after the Swiss engineer Conrad Matschoss extended the history of technology to industrial monuments in 1932 [105]. Figure 20 shows the measurement of points by laser scan of a Roman mosaic in Cantillana, Seville (Spain).
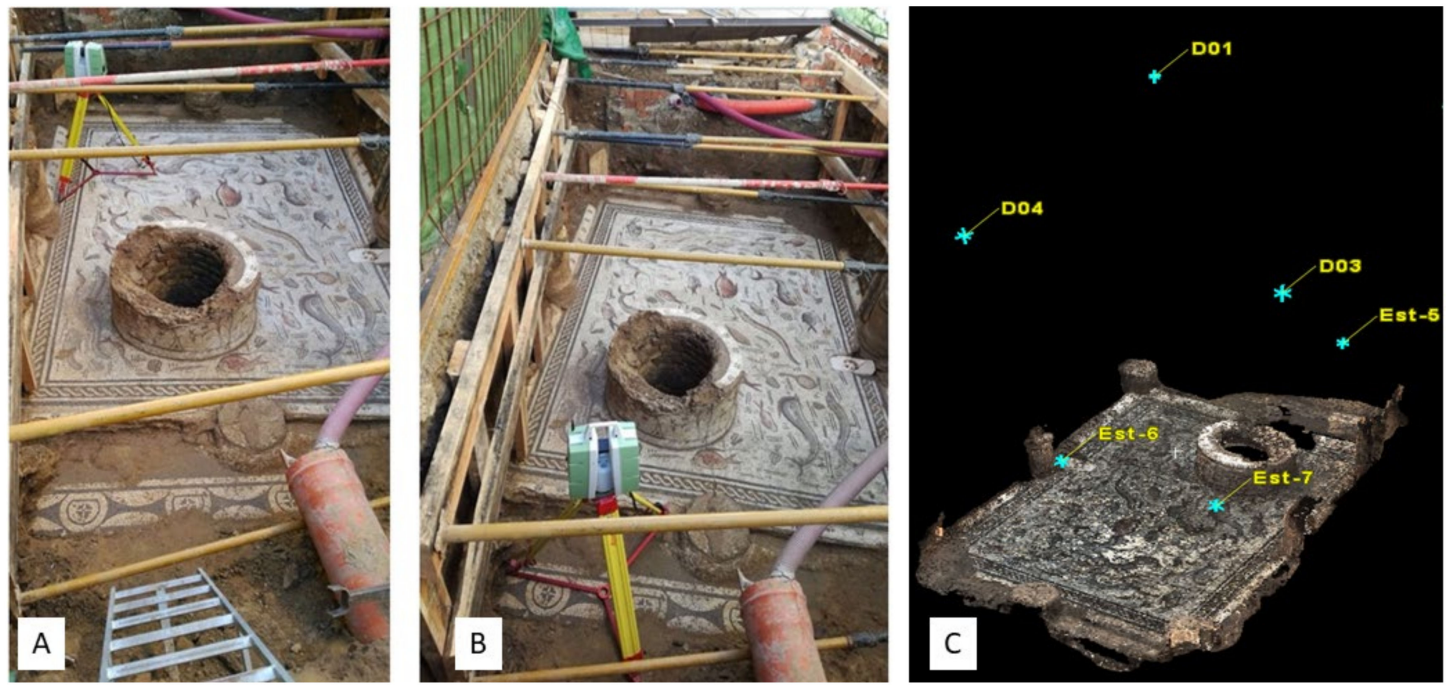

Figure 20. Roman mosaic in Cantillana, Seville (Spain). (A,B) Measurement of points by laser scan at different positions. (C) Result as cloud of points. 
The last cluster, cluster 8 , is focused on virtual reconstruction, and once the models are generated, even make a 3D print of them as a scientific dissemination, or heritage preservation, because sometimes it is not possible to expose the original and a copy of it is exposed, either at a 1:1 scale, or at another scale so that it can be adapted to the place of exhibition. To cite some examples of 3D reconstruction from image sequences, in order to make photo-realistic digital (and physical) replicas for an exhibition and for 3D visualization in virtual museum applications, there is the exhibition "Treasures of Vietnamese Archaeology and Culture", in which cultural heritage objects from different Vietnamese museums were selected and digitised in September 2015 [106]. The Vietnamese Treasures, which have never been exhibited outside Vietnam, could be shown for the first time in Germany in the context of three exhibitions in the cities of Herne, Chemnitz and Mannheim between October 2016 and February 2018. This certainly allows another dimension to be given to cultural heritage without putting it at risk. A great example in Spain is the replica of the Altamira Cave, the so-called neo-cave that is actually visited, to preserve the original. From 28 pairs of photographs, a very accurate representation in relief was obtained. From the images, the photogrammetry allows to establish a precise cartography of the ceiling, with equidistant contour lines of $2 \mathrm{~cm}$. The superimposition of the photographic coverage made it possible to position each of the cave paintings with great precision [107]. However, the enormous effort and costs that must be invested to obtain realistic models remains a problem [108], which is why the line of low-cost solutions must be worked on [109]. Figure 21 shows the virtual reconstruction of Doña Blanca castle, 8th century B.C., from the archaeological site data and written documentation of the site and other sources of information.

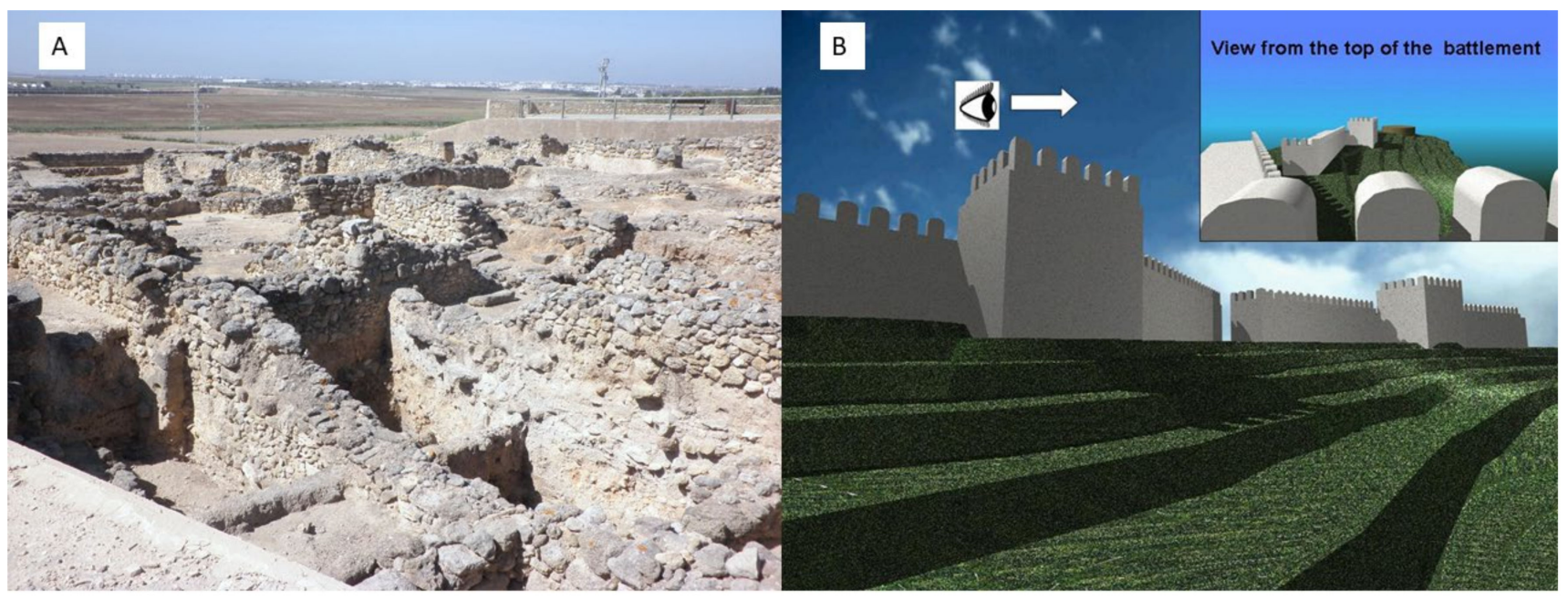

Figure 21. Virtual recreation of the Doña Blanca castle. (A) Archaeological site in its current state. (B) Virtual reconstruction of the fortification wall.

Geometric survey has traditionally been one of the tasks to be carried out in the analysis of an archaeological site. The preservation of the site's elements requires non-invasive methods that allow the same or a higher degree of precision that can be achieved using traditional surveying and drawing techniques. The main advantage of photogrammetry is, besides being a non-invasive method as with the traditional ones, to be able to extract all the information in 3D and to work on large areas. In this framework, 3D modelling techniques using photogrammetry and laser scanning appear to be an appropriate solution. Finally, it is worth mentioning the importance of using 3D technologies as a tool to improve archaeological research and increase the production of information from archaeological data for analysis and interpretation in 4D [110]. To visualise evolution over longer time periods within archaeology, the three spatial dimensions of virtual space can be extended with time as a fourth dimension, so-called 4D visualisation techniques [111]. An example 
of this is the work on a "nuraghe", a typical megalithic monument built only in Sardinia during the Bronze Age [112].

In the latter respect, important projects are being developed showing that it is possible to add a multi-temporal and multi-scale perspective to field excavation, as financed by the Swedish Research Council [113].

\section{Conclusions}

Archaeology should be understood as a multidisciplinary scientific discipline, which uses other scientific fields' technologies to improve the recording and interpretation of data from archaeological surveys. Photogrammetry is playing an essential role in this context by providing visual information from the photograph at the field level, with the information from the photograph and with metric accuracy. In this research, it has been observed that the first uses of photogrammetry in archaeology date back to 1962, but it is not until 2010 that an exponential growth in publications can be noticed. The most prominent scientific categories have been social science $(26 \%)$, where archaeological studies are partially included, and computer science $(24 \%)$. This shows both the importance of photogrammetry for archaeology and the interest of computer science in promoting photogrammetric tools for application in archaeology. The leading institutions in this field of research are the central research institutions of France (CNRS Centre National de la Recherche Scientifique) and Italy (Consiglio Nazionale delle Ricerche). In third place, there is a Spanish university, the University of Salamanca. By country, publications in this field are led by Italy, followed by the USA, Spain, France, and the United Kingdom.

Photogrammetry was applied until 2008 for cartography (maps) and as a basic tool for drawing with CAD systems; then, in 2010, this cartographic information was integrated into GIS and virtual reconstructions were carried out; it was also proposed as a tool for cultural heritage. Subsequently, in 2012, HDS was used for data capture and 3D models of objects became popular. In 2014, UAV flights and LiDAR systems were combined to make large-scale 3D reconstructions. The main lines of research in photogrammetry applied to archaeology are close range photogrammetry, aerial photogrammetry (UAV), cultural heritage, excavation, cameras, GPS, laser scan, virtual reconstruction, and 3D printing. Of these trends, underwater archaeology has not yet emerged as a cluster, perhaps because the specific publications on this topic do not yet cover the possibilities of underwater photogrammetry. The reconstruction of archaeological data is a time-consuming and multidisciplinary research process, as archaeologists must deal with large datasets and complex multifaceted archaeological information stored and spread across different types of media and documents. As the use of multimedia data acquisition is rapidly increasing, as seen in this research, archaeological information systems must in the future allow for $3 \mathrm{D}$ visualization in the form of virtual reality, and to help understand its evolution the integration of multimedia and visualization of temporally and/or spatially referenced data will lead to the emergence of so-called $4 \mathrm{D}$ techniques. In conclusion, it can be said that the development of photogrammetry opens up new perspectives for archaeology.

Author Contributions: Conceptualization, F.M.-A. and J.L.L.-C.; methodology, F.M.-A. and J.L.L.-C.; software, C.M.-B. and A.P.-R.; validation, C.M.-B. and A.P.-R.; formal analysis, C.M.-B. and A.P.-R.; data curation, C.M.-B. and A.P.-R.; writing-original draft preparation, F.M.-A., C.M.-B. and A.P.-R.; writing-review and editing, F.M.-A., I.B.J. and J.L.L.-C.; supervision, F.M.-A., I.B.J. and J.L.L.-C.; project administration, I.B.J. and J.L.L.-C.; funding acquisition, I.B.J. and J.L.L.-C. All authors have read and agreed to the published version of the manuscript.

Funding: This work was funded by the Spanish Ministry of Economy and Competitiveness under the research projects HAR2014-53350-P and HAR2017-86334-R.

Institutional Review Board Statement: Not applicable.

Informed Consent Statement: Not applicable.

Data Availability Statement: Data retrieved from Scopus database. 
Acknowledgments: The authors would like to thank to the CIAIMBITAL (University of Almeria, CeiA3) for its support.

Conflicts of Interest: The authors declare no conflict of interest.

\section{References}

1. Hussain, S.T.; Will, M. Materiality, agency and evolution of lithic technology: An integrated perspective for Palaeolithic Archaeology. J. Archaeol. Method Theory 2020, 1-54. [CrossRef]

2. Cowley, D.C.; Stichelbaut, B.B. Historic aerial photographic archives for European Archaeology. Eur. J. Archaeol. 2012, 15, 217-236. [CrossRef]

3. Nakamura, T.; Taniguchi, Y.; Tsuji, S.I.; Oda, H. Radiocarbon dating of charred residues on the earliest pottery in Japan. Radiocarbon 2001, 43, 1129-1138. [CrossRef]

4. Blakelock, E.; Martinón-Torres, M.; Veldhuijzen, H.A.; Young, T. Slag inclusions in iron objects and the quest for provenance: An experiment and a case study. J. Archaeol. Sci. 2009, 36, 1745-1757. [CrossRef]

5. Charlton, M.F.; Blakelock, E.; Martinón-Torres, M.; Young, T. Investigating the production provenance of iron artifacts with multivariate methods. J. Archaeol. Sci. 2012, 39, 2280-2293. [CrossRef]

6. Dunnell, R.C.; Dancey, W.S. The siteless survey: A regional scale data collection strategy. In Advances in Archaeological Method and Theory; Academic Press: Cambridge, MA, USA, 1983; pp. 267-287.

7. Barker, P. Techniques of Archaeological Excavation; Psychology Press: Brighton and Hove, UK, 1993.

8. Gosh, S. History of Photogrammetry; Laval University: Québec City, QC, Canada, 1981.

9. Polidori, L. On Laussedat's Contribution to the Emergence of Photogrammetry. Int. Arch. Photogramm. Remote Sens. Spat. Inf. Sci. 2020, 43, 893-899. [CrossRef]

10. Albertz, J. A look back. Photogramm. Eng. Remote Sens. 2007, 73, 504-506.

11. Bervoets, S.G. Review of developments in Photogrammetry. Aust. Surv. 1969, 22, 529-540. [CrossRef]

12. Capper, J.E. Photographs of Stonehenge as seenfrom a War Balloon. Archaeologia 1907, 60, 571. [CrossRef]

13. Da Silva, D.C. Evolution of Photogrammetry in Brazil. Rev. Bras. De Cartogr. 2012, 64.

14. Pérez, J.A.; Bascon, F.M.; Charro, M.C. Photogrammetric usage of 1956-57 USAF aerial photography of Spain. Photogramm. Rec. 2014, 29, 108-124. [CrossRef]

15. Pavlidis, G.; Koutsoudis, A.; Arnaoutoglou, F.; Tsioukas, V.; Chamzas, C. Methods for 3D digitization of cultural heritage. J. Cult. Herit. 2007, 8, 93-98. [CrossRef]

16. Luo, L.; Wang, X.; Guo, H.; Lasaponara, R.; Shi, P.; Bachagha, N.; Hu, N. Google Earth as a powerful tool for archaeological and cultural heritage applications: A review. Remote Sens. 2018, 10, 1558.

17. Kumar, L.; Mutanga, O. Google Earth Engine applications since inception: Usage, trends, and potential. Remote Sens. 2018, 10, 1509. [CrossRef]

18. Verde, N.; Kokkoris, I.P.; Georgiadis, C.; Kaimaris, D.; Dimopoulos, P.; Mitsopoulos, I.; Mallinis, G. National Scale Land Cover Classification for Ecosystem Services Mapping and Assessment, Using Multitemporal Copernicus EO Data and Google Earth Engine. Remote Sens. 2020, 12, 3303. [CrossRef]

19. Colomina, I.; Molina, P. Unmanned aerial systems for Photogrammetry and remote sensing: A review. ISPRS J. Photogramm. Remote Sens. 2014, 92, 79-97. [CrossRef]

20. Mozas-Calvache, A.T.; Pérez-García, J.L.; Cardenal-Escarcena, F.J.; Mata-Castro, E.; Delgado-García, J. Method for photogrammetric surveying of archaeological sites with light aerial platforms. J. Archaeol. Sci. 2012, 39, 521-530. [CrossRef]

21. Themistocleous, K.; Ioannides, M.; Agapiou, A.; Hadjimitsis, D.G. The methodology of documenting cultural heritage sites using Photogrammetry, UAV, and 3D printing techniques: The case study of Asinou Church in Cyprus. In Proceedings of the Third International Conference on Remote Sensing and Geoinformation of the Environment (RSCy2015) (Vol. 9535, p. 953510). Int. Soc. Opt. Photonics 2015, 39, 521-530.

22. Leon, I.; Pérez, J.J.; Senderos, M. Advanced techniques for fast and accurate heritage digitisation in multiple case studies. Sustainability 2020, 12, 6068. [CrossRef]

23. Williamson, J.; Nicu, I.C. Photogrammetric Measurement of Erosion at the Sabbath Point Beothuk Site in Central Newfoundland, Canada. Sustainability 2020, 12, 7555. [CrossRef]

24. Perea-Moreno, A.J.; Aguilera-Ureña, M.J.; Larriva, M.D.; Manzano-Agugliaro, F. Assessment of the potential of UAV video image analysis for planning irrigation needs of golf courses. Water 2016, 8, 584.

25. Andrés, A.N.; Pozuelo, F.B.; Marimón, J.R.; de Mesa Gisbert, A. Generation of virtual models of cultural heritage. J. Cult. Herit. 2012, 13, 103-106. [CrossRef]

26. Novas, N.; Álvarez-Bermejo, J.A.; Valenzuela, J.L.; Gázquez, J.A.; Manzano-Agugliaro, F. Development of a smartphone application for assessment of chilling injuries in zucchini. Biosyst. Eng. 2019, 181, 114-127. [CrossRef]

27. Clement, J.; Novas, N.; Gázquez, J.A.; Manzano-Agugliaro, F. High speed intelligent classifier of tomatoes by colour, size and weight. Span. J. Agric. Res. 2012, 10, 314-325. [CrossRef]

28. Clement, J.; Novas, N.; Gazquez, J.A.; Manzano-Agugliaro, F. An active contour computer algorithm for the classification of cucumbers. Comput. Electron. Agric. 2013, 92, 75-81. [CrossRef]

29. Evans, R.M. Maxwell's color photograph. Sci. Am. 1961, 205, 118-131. [CrossRef] 
30. Verhoeven, G.J.; Schmitt, K.D. An attempt to push back frontiers—Digital near-ultraviolet aerial archaeology. J. Archaeol. Sci. 2010, 37, 833-845. [CrossRef]

31. Casana, J.; Kantner, J.; Wiewel, A.; Cothren, J. Archaeological aerial thermography: A case study at the Chaco-era Blue J community, New Mexico. J. Archaeol. Sci. 2014, 45, 207-219. [CrossRef]

32. Giardino, M.J. A history of NASA remote sensing contributions to archaeology. J. Archaeol. Sci. 2011, 38, 2003-2009. [CrossRef]

33. Garrison, T.G.; Houston, S.D.; Golden, C.; Inomata, T.; Nelson, Z.; Munson, J. Evaluating the use of IKONOS satellite imagery in lowland Maya settlement archaeology. J. Archaeol. Sci. 2008, 35, 2770-2777. [CrossRef]

34. De Laet, V.; Paulissen, E.; Waelkens, M. Methods for the extraction of archaeological features from very high-resolution Ikonos-2 remote sensing imagery, Hisar (southwest Turkey). J. Archaeol. Sci. 2007, 34, 830-841. [CrossRef]

35. Zhou, X.; Zhang, C.; Pan, Z.; Wei, P. Tourism Industry is Leading the Digital Transformation of Cultural Heritage Management: Bibliometric Analysis Based on Web of Science Database. In Proceedings of the Management Science Informatization and Economic Innovation Development Conference (MSIEID), Guangzhou, China, 18-20 December 2020; pp. 273-276.

36. Papworth, H.; Ford, A.; Welham, K.; Thackray, D. Assessing 3D metric data of digital surface models for extracting archaeological data from archive stereo-aerial photographs. J. Archaeol. Sci. 2016, 72, 85-104. [CrossRef]

37. Elfadaly, A.; Eldein, A.S.; Lasaponara, R. Cultural Heritage Management Using Remote Sensing Data and GIS Techniques around the Archaeological Area of Ancient Jeddah in Jeddah City, Saudi Arabia. Sustainability 2019, 12, 240. [CrossRef]

38. Agapiou, A.; Lysandrou, V. Remote sensing archaeology: Tracking and mapping evolution in European scientific literature from 1999 to 2015. J. Archaeol. Sci. Rep. 2015, 4, 192-200. [CrossRef]

39. Garrido-Cardenas, J.A.; Mesa-Valle, C.; Manzano-Agugliaro, F. Trends in plant research using molecular markers. Planta 2018, 247, 543-557. [CrossRef]

40. Salmerón-Manzano, E.; Manzano-Agugliaro, F. Unaccompanied Minors: Worldwide Research Perspectives. Publications 2019, 7, 2. [CrossRef]

41. Garrido-Cardenas, J.A.; de Lamo-Sevilla, C.; Cabezas-Fernández, M.T.; Manzano-Agugliaro, F.; Martínez-Lirola, M. Global tuberculosis research and its future prospects. Tuberculosis 2020, 121, 101917.

42. Muyor-Rodriguez, J.; Manzano-Agugliaro, F.; Garrido-Cardenas, J.A. The state of global research on social work and disability. Soc. Work Health Care 2019, 58, 839-853. [CrossRef]

43. Salmeron-Manzano, E.; Manzano-Agugliaro, F. The electric bicycle: Worldwide research trends. Energies 2018, 11, 1894.

44. Van Eck, N.J.; Waltman, L. Software survey: VOSviewer, a computer program for bibliometric mapping. Scientometrics 2010, 84, 523-538. [CrossRef]

45. Guerrero, M.; Montoya, F.G.; Baños, R.; Alcayde, A.; Gil, C. Adaptive community detection in complex networks using genetic algorithms. Neurocomputing 2017, 266, 101-113. [CrossRef]

46. Guerrero, M.; Montoya, F.G.; Baños, R.; Alcayde, A.; Gil, C. Community detection in national-scale high voltage transmission networks using genetic algorithms. Adv. Eng. Inform. 2018, 38, 232-241. [CrossRef]

47. Guerrero, M.; Baños, R.; Gil, C.; Montoya, F.G.; Alcayde, A. Evolutionary Algorithms for Community Detection in ContinentalScale High-Voltage Transmission Grids. Symmetry 2019, 11, 1472. [CrossRef]

48. Waltman, L.; Van Eck, N.J. A smart local moving algorithm for large-scale modularity-based community detection. Eur. Phys. J. B 2013, 86, 471. [CrossRef]

49. Newman, M.E. Fast algorithm for detecting community structure in networks. Phys. Rev. E 2004, 69, 066133. [CrossRef]

50. Leicht, E.A.; Newman, M.E. Community structure in directed networks. Phys. Rev. Lett. 2008, 100, 118703. [CrossRef]

51. Cobo, M.J.; López-Herrera, A.G.; Herrera-Viedma, E.; Herrera, F. SciMAT: A new science mapping analysis software tool. J. Am. Soc. Inf. Sci. Technol. 2012, 63, 1609-1630. [CrossRef]

52. Garrido-Cardenas, J.A.; Mesa-Valle, C.; Manzano-Agugliaro, F. Human parasitology worldwide research. Parasitology 2018, 145, 699-712. [CrossRef]

53. Nex, F.; Remondino, F. UAV for 3D mapping applications: A review. Appl. Geomat. 2014, 6, 1-15. [CrossRef]

54. Orihuela, A.; Molina-Fajardo, M.A. UAV Photogrammetry Surveying for Sustainable Conservation: The Case of Mondújar Castle (Granada, Spain). Sustainability 2021, 13, 24. [CrossRef]

55. De Stefano, R.; Repola, L.; Guerriero, L.; Iovane, D.; Morra, V.; Pagano, F.; Di Martire, D. Rockfall Threatening Cumae Archeological Site Fruition (Phlegraean Fields Park-Naples). Sustainability 2021, 13, 1390. [CrossRef]

56. Farhood, H.; Perry, S.; Cheng, E.; Kim, J. Enhanced 3D point cloud from a light field image. Remote Sens. 2020, 12, 1125. [CrossRef]

57. Ferrer-González, E.; Agüera-Vega, F.; Carvajal-Ramírez, F.; Martínez-Carricondo, P. UAV Photogrammetry Accuracy Assessment for Corridor Mapping Based on the Number and Distribution of Ground Control Points. Remote Sens. 2020, 12, 2447. [CrossRef]

58. Millon, R. The Teotihuacan mapping project. Am. Antiq. 1964, 29, 345-352. [CrossRef]

59. Millon, R.; Altschul, J.H. The making of the map: The origin and lessons of the Teotihuacan Mapping Project. Anc. Mesoam. 2015, 26, 135. [CrossRef]

60. Cowgill, G.L. The Teotihuacan Mapping Project: Experiences with data files, big questions, and some research priorities for Teotihuacan. Anc. Mesoam. 2015, 26, 153. [CrossRef]

61. Newcomb, R.M. Celtic fields in Himmerland, Denmark, as revealed by vertical photography at a scale of 1:25,000. Photogrammetria 1971, 27, 101-113. [CrossRef] 
62. Castro, J.L.L.; Manzano-Agugliaro, F.; Ochotorena, B.A. Altos de Reveque: Un asentamiento fortificado fenicio-púnico en el litoral de Andalucía oriental. Archivo Español de Arqueología 2010, 83, 27-46. [CrossRef]

63. Hood, J.S.R. Photogrammetry and field Archaeology. Antiquity 1977, 51, 151.

64. Drap, P.; Merad, D.; Hijazi, B.; Gaoua, L.; Nawaf, M.M.; Saccone, M.; Castro, F. Underwater Photogrammetry and object modeling: A case study of Xlendi Wreck in Malta. Sensors 2015, 15, 30351-30384. [CrossRef]

65. Mahiddine, A.; Seinturier, J.; Bö̈, D.P.J.M.; Drap, P.; Merad, D.; Long, L. Underwater image preprocessing for automated Photogrammetry in high turbidity water: An application on the Arles-Rhone XIII roman wreck in the Rhodano river, France. In Proceedings of the 18th International Conference on Virtual Systems and Multimedia, Milan, Italy, 2-5 September 2012; pp. 189-194.

66. Drap, P.; Seinturier, J.; Hijazi, B.; Merad, D.; Boi, J.M.; Chemisky, B.; Long, L. The ROV 3D Project: Deep-sea underwater survey using Photogrammetry: Applications for underwater Archaeology. J. Comput. Cult. Herit. 2015, 8, 1-24. [CrossRef]

67. Dell'Unto, N.; Landeschi, G.; Touati, A.M.L.; Dellepiane, M.; Callieri, M.; Ferdani, D. Experiencing ancient buildings from a 3D GIS perspective: A case drawn from the Swedish Pompeii Project. J. Archaeol. Method Theory 2016, 23, 73-94. [CrossRef]

68. Pierdicca, R.; Frontoni, E.; Malinverni, E.S.; Colosi, F.; Orazi, R. Virtual reconstruction of archaeological heritage using a combination of photogrammetric techniques: Huaca Arco Iris, Chan Chan, Peru. Digit. Appl. Archaeol. Cult. Herit. 2016, 3, 80-90. [CrossRef]

69. Gonzalez-Aguilera, D.; Lahoz, J.; Finat, J.; Martinez, J.; Fernandez, J.; San Josem, J. Terrestrial laser Canning and low-cost aerial Photogrammetry in the archeological modeling of a Jewish tanneries. Int. Arch. Photogram. Remote Sens. 2006, $38,5$.

70. Neto, F.A. 3D modeling and Photogrammetry-supported GIS in Archaeology. Int. Arch. Photogramm. Remote Sens. Spat. Inf. Sci. ISPRS Arch. 2000, 33, 574-579.

71. Smith, N.G.; Knabb, K.; DeFanti, C.; Weber, P.; Schulze, J.; Prudhomme, A.; DeFanti, T.A. ArtifactVis2: Managing real-time archaeological data in immersive 3D environments. In Proceedings of the Digital Heritage International Congress (DigitalHeritage), Marseille, France, 28 October-1 November 2013; Volume 1, pp. 363-370.

72. Smith, N.G.; Howland, M.; Levy, T.E. Digital Archaeology field recording in the 4th dimension: ArchField C++ a 4D GIS for digital field work. In Proceedings of the Digital Heritage, Granada, Spain, 28 September-2 October 2015; Volume 2, pp. 251-258.

73. Liang, J.; Gong, J.; Li, W. Applications and impacts of Google Earth: A decadal review (2006-2016). ISPRS J. Photogramm. Remote Sens. 2018, 146, 91-107. [CrossRef]

74. San-Antonio-Gómez, C.; Velilla, C.; Manzano-Agugliaro, F. Photogrammetric techniques and surveying applied to historical map analysis. Surv. Rev. 2015, 47, 115-128. [CrossRef]

75. Daakir, M.; Pierrot-Deseilligny, M.; Bosser, P.; Pichard, F.; Thom, C.; Rabot, Y. Study of lever-arm effect using embedded photogrammetry and on-board GPS receiver on UAV for metrological mapping purpose and proposal of a free ground measurements calibration procedure. Int. Arch. Photogramm. Remote Sens. Spat. Inf. Sci. 2016, XL-3/W4, 65-70. [CrossRef]

76. La Cruz-Lovera, D.; Perea-Moreno, A.J.; la Cruz-Fernández, D.; Alvarez-Bermejo, J.A.; Manzano-Agugliaro, F. Worldwide research on energy efficiency and sustainability in public buildings. Sustainability 2017, 9, 1294. [CrossRef]

77. Song, D.; Yang, W.; Zhao, P. Photogrammetry and remote sensing project in survey of the Emperor Qin Shi Huang's mausoleum. In Close-Range Photogrammetry Meets Machine Vision; International Society for Optics and Photonics: Bellingham, WA, USA, 1990; Volume 1395, p. 13952F.

78. Addison, A.C.; Gaiani, M. Virtualized architectural heritage: New tools and techniques. IEEE Multimed. 2000, 7, 26-31. [CrossRef]

79. Homainejad, A.S. Close Range Photogrammetric Technique For Documentation Of Naqsh-I Rustam. In Proceedings of the International Archives Of Photogrammetry And Remote Sensing, Amsterdam, The Netherlands, 16-23 July 2000 ; pp. 366-371.

80. Fujii, Y.; Fodde, E.; Watanabe, K.; Murakami, K. Digital Photogrammetry for the documentation of structural damage in earthen archaeological sites: The case of Ajina Tepa, Tajikistan. Eng. Geol. 2009, 105, 124-133. [CrossRef]

81. Lerma, J.L.; Navarro, S.; Cabrelles, M.; Villaverde, V. Terrestrial laser scanning and close range Photogrammetry for 3D archaeological documentation: The Upper Palaeolithic Cave of Parpalló as a case study. J. Archaeol. Sci. 2010, 37, $499-507$. [CrossRef]

82. Grussenmeyer, P.; Landes, T.; Alby, E.; Carozza, L. High resolution 3D recordng and modelling on the Bronze Age cave" les Fraux" in Perigord (France). In Proceedings of the Conference ISPRS Commission V Symposium, Newcastle upon Tyne, UK, 21-24 June 2010; Volume 38, pp. 262-267.

83. Theodoridou, S.; Tokmakidis, K.; Skarlatos, D. Use of radio-controlled model helicopters in Archaeology surveying and in building construction industry. Int. Arch. Photogramm. Remote Sens. 2000, 33, 825-829.

84. Altan, M.O.; Celikoyan, T.M.; Kemper, G.; Toz, G. Balloon Photogrammetry for cultural heritage. International Archives of the Photogrammetry. Remote Sens. Spat. Inf. Sci. 2004, 35, 964-968.

85. Eisenbeiss, H.; Zhang, L. Comparison of DSMs generated from mini UAV imagery and terrestrial laser scanner in a cultural heritage application. Int. Arch. Photogramm. Remote Sens. Spat. Inf. Sci. 2006, 36, 90-96.

86. Corns, A.; Shaw, R. High resolution 3-dimensional documentation of archaeological monuments \& landscapes using airborne LIDAR. J. Cult. Herit. 2009, 10, e72-e77. 
87. Bendea, H.; Chiabrando, F.; Tonolo, F.G.; Marenchino, D. Mapping of archaeological areas using a low-cost UAV. The Augusta Bagiennorum test site. In Proceedings of the XXI International CIPA Symposium, Athens, Greece, 1-6 October 2007 ; Volume 1.

88. Cardoso, J.L.; Castro, J.L.L.; Ferjaoui, A.; Martín, A.M.; Hahnmüller, V.M.; Jerbania, I.B. What the people of Utica (Tunisia) ate at a banquet in the 9th century BCE. ZooArchaeology of a North African early Phoenician settlement. J. Archaeol. Sci. Rep. 2016, 8 , 314-322. [CrossRef]

89. Nieto-Julián, J.E.; Lara, L.; Moyano, J. Implementation of a TeamWork-HBIM for the Management and Sustainability of Architectural Heritage. Sustainability 2021, 13, 2161.

90. Bitelli, G.; Tini, M.A.; Vittuari, L. Close-range Photogrammetry, virtual reality and their integration in Archaeology. In Proceedings of the 19th International Congress for Photogrammetry and Remote Sensing, ISPRS 2000, Amsterdam, The Netherlands, 16-23 July 2000; Volume 33, pp. 872-879.

91. Meyer, É.; Grussenmeyer, P.; Tidafi, T.; Parisel, C.; Revez, J. Photogrammetry for the epigraphic survey in the great hypostyle hall of Karnak temple: A new approach. In Proceedings of the XXth Congress of the ISPRS, Istanbul, Turkey, 12-23 July 2004; pp. 12-23.

92. Koistinen, K. 3D Documentation for Archaeology during Finnish Jabal Haroun project. Int. Arch. Photogramm. Remote Sens. 2000, $33,440-445$.

93. Sauerbier, M.; Eisenbeiss, H. UAVs for the documentation of archaeological Excavations. Int. Arch. Photogramm. Remote Sens. Spat. Inf. Sci. 2010, 38, 526-531.

94. Núñez, M.A.; Buill, F.; Edo, M. 3D model of the Can Sadurní cave. J. Archaeol. Sci. 2013, 40, 4420-4428. [CrossRef]

95. Cobos, Ó.J.C.; Rogina, P.S.; Vega, L.T.; López, Ó.R.; Casuso, D.A.; Almazán, D.V.; Vidal, E.S. Virtual documentation of different structures in the urban archaeological site of Velarde Square in Santander. In Proceedings of the Digital Heritage, Granada, Spain, 28 September-2 October 2015; Volume 2, pp. 691-694.

96. Pollefeys, M.; Koch, R.; Vergauwen, M.; Van Gool, L. Automated reconstruction of 3D scenes from sequences of images. ISPRS J. Photogramm. Remote Sens. 2000, 55, 251-267. [CrossRef]

97. Zakaria, A.M.; Said, A.M. 3D reconstruction of a scene from multiple uncalibrated images using close range Photogrammetry. In Proceedings of the IEEE International Symposium on Information Technology, Bradford, UK, 29 June-1 July 2010; Volume 1, pp. $1-5$.

98. Moslah, O.; Valles-Such, A.; Guitteny, V.; Couvet, S.; Philipp-Foliguet, S. Accelerated multi-view stereo using parallel processing capababilities of the GPUs. In Proceedings of the 3DTV Conference: The True Vision-Capture, Transmission and Display of 3D Video, Potsdam, Germany, 4-6 May 2009; pp. 1-4.

99. Orengo, H.A. Combining terrestrial stereoPhotogrammetry, DGPS and GIS-based 3D voxel modelling in the volumetric recording of archaeological features. ISPRS J. Photogramm. Remote Sens. 2013, 76, 49-55. [CrossRef]

100. Yastikli, N. Documentation of cultural heritage using digital Photogrammetry and laser scanning. J. Cult. Herit. 2007, 8, 423-427. [CrossRef]

101. Liang, H.; Li, W.; Lai, S.; Zhu, L.; Jiang, W.; Zhang, Q. The integration of terrestrial laser scanning and terrestrial and unmanned aerial vehicle digital Photogrammetry for the documentation of Chinese classical gardens-A case study of Huanxiu Shanzhuang, Suzhou, China. J. Cult. Herit. 2018, 33, 222-230. [CrossRef]

102. Rojas-Sola, J.I.; Amezcua-Ogáyar, J.M. Southern spanish windmills: Technological aspects. Renew. Energy 2005, 30 , 1943-1953. [CrossRef]

103. Pérez-Martín, E.; Herrero-Tejedor, T.R.; Gómez-Elvira, M.Á.; Rojas-Sola, J.I.; Conejo-Martin, M.Á. Graphic study and geovisualization of the old windmills of La Mancha (Spain). Appl. Geogr. 2011, 31, 941-949. [CrossRef]

104. Rojas-Sola, J.I.; Galán-Moral, B.; la Morena-De la Fuente, D. Agustín de Betancourt's Double-Acting Steam Engine: Geometric Modeling and Virtual Reconstruction. Symmetry 2018, 10, 351. [CrossRef]

105. Gruenkemeier, A. 3D-documentation technologies for use in industrial Archaeology applications. The International Archives of the Photogrammetry, Remote Sensing and Spatial Information Sciences, 37. In Proceedings of the 21st ISPRS International Congress for Photogrammetry and Remote Sensing, Beijing, China, 3-11 July 2008; Volume 37, pp. $291-295$.

106. Kersten, T.P. 3D Models and Virtual Tours for a Museum Exhibition of Vietnamese Cultural Heritage Exhibits and Sites. In Euro-Mediterranean Conference; Springer: Cham, Switzerland, 2018; Volume 11196, pp. 528-538.

107. Museo de Altamira. 2018. Available online: http://www.culturaydeporte.gob.es/mnaltamira/dam/jcr:5acc5e6f-51b4-403c-a0a0 -40effcc7cfea/catalogo-el-aerte-de-reproducir-el-arte.pdf (accessed on 18 July 2020).

108. Reinoso-Gordo, J.F.; Barsky, D.; Serrano-Ramos, A.; Solano-García, J.A.; León-Robles, C.A.; Luzón-González, C.; Jiménez-Arenas, J.M. Walking among Mammoths. Remote Sensing and Virtual Reality Supporting the Study and Dissemination of Pleistocene Archaeological Sites: The Case of Fuente Nueva 3 in Orce, Spain. Sustainability 2020, 12, 4785. [CrossRef]

109. Salmerón-Manzano, E.; Manzano-Agugliaro, F. Worldwide Research on Low Cost Technologies through Bibliometric Analysis. Inventions 2020, 5, 9. [CrossRef]

110. Rodríguez-Gonzálvez, P.; Muñoz-Nieto, A.L.; del Pozo, S.; Sanchez-Aparicio, L.J.; Gonzalez-Aguilera, D.; Micoli, L.; Hejmanowska, B. 4D reconstruction and visualization of cultural heritage: Analyzing our legacy through time. Int. Arch. Photogramm. Remote Sens. Spat. Inf. Sci. 2017, 42, 609. [CrossRef] 
111. Kulitz, I.; Ferschin, P. Archaeological Information Systems. In Scientific Computing and Cultural Heritage; Springer: Berlin/Heidelberg, Germany, 2013; pp. 147-155.

112. Lai, L.; Sordini, M.; Campana, S.; Usai, L.; Condò, F. 4D recording and analysis: The case study of Nuraghe Oes (Giave, Sardinia). Digit. Appl. Archaeol. Cult. Herit. 2015, 2, 233-239. [CrossRef]

113. Dell'Unto, N.; Landeschi, G.; Apel, J.; Poggi, G. 4D recording at the trowel's edge: Using three-dimensional simulation platforms to support field interpretation. J. Archaeol. Sci. Rep. 2017, 12, 632-645. [CrossRef] 